\title{
DOCTOR AUGUSTINE, PHYSICIAN TO CARDINAL WOLSEY AND KING HENRY VIII
}

\author{
by
}

\author{
E. A. HAMMOND*
}

\section{THE WOLSEY YEARS}

It is odd that Augustine de Augustinis, M.D., native of Venice but denizen of England for more than twenty years, has not drawn more attention from Tudor historians. Until the publication in 1960 of the first volume of the Dizionario Biografico degli Italiani (Rome, 1960- ), which includes Mario Rosa's sketch, only meagre biographical details had appeared in print. And yet Augustine's service as the personal physician of Cardinal Wolsey and his subsequent position as physician-inordinary to King Henry VIII projected him into the mainstream of English political life. In the former post he had been a colleague of Thomas Cromwell, who was to discover in him a useful agent for espionage and diplomacy, while his propinquity to the monarch during the Reformation years enabled him to profit munificently from the allocation of ecclesiastical properties and transformed him in remarkably short order from household servant to member of the bourgeoisie.

The career of Augustine bears a bizarre, even sinister, quality. His political assignments, frequently carried out in the penumbral milieu of Renaissance diplomacy, now and then took him away from the court itself into the shadowy world of taverns, inns and back streets, not only in London, but in Antwerp, Brussels, Regensberg, Bologna, Florence and Rome. There he trafficked in the intrigues whose details it was his mission to seek out and report to his employers at the English court. The fact that he survived two arrests and two incarcerations in the Tower of London stamps him as a nimble agent and suggests why he was able to end his days quietly in Lucca. He seems always to have been held in slight distrust, even by his employers, but his linguistic skills and his talent for espionage rendered him useful, and in the diplomatic world of the early sixteenth century who could be more useful than a medical spy whose access to the bedchambers of political personages was taken for granted? Shortly after he had risen to prominence in the household of Wolsey, Augustine came to the attention of Claude Dodieu, secretary to the French embassy in London, who found him "very uneasy in his manner and suspicious". 1

${ }^{*}$ E. A. Hammond, Ph.D., Department of History, University of Florida, Gainesville 32611, U.S.A.

${ }^{1}$ Calendar of Letters and Papers, Foreign and Domestic, Henry VIII, edited by J. S. Brewer (vols. 1 to 4), J. Gairdner (vols. 5 to 13), J. Gairdner and R. H. Brodie (vols. 14 to 21), Addendum (Pts. 1 and 2) (London, 1864-1932), IV (ii), 3105. This extensive collection is hereinafter cited as $L P$. Arabic numerals refer to items, not pages, unless in parentheses. In most instances, especially those requiring a critical reading, the original documents in the Public Record Office or the British Museum have been examined. For documents in Austrian, Spanish and Italian archives, the calendars only have been used. 


\section{E. A. Hammond}

Not much is known of Augustine's early life. Born in Venice, ${ }^{2}$ probably about the beginning of the sixteenth century, he was commonly known as "the Venetian" or "the Venetian physician", even after his denization as an English citizen. One is tempted to conjecture that his medical degree was conferred by the University of Padua, whose medical school enjoyed such renown during the sixteenth century, but his name does not appear on any surviving list of Paduan matriculants of the period. ${ }^{3}$ His presence in England can probably be explained by the arrival in England of his uncle, Girolamo Ghinucci, as papal nuncio. Ghinucci's subsequent appointment to the bishopric of Worcester opened the doors of Wolsey's household to young Augustine. From the very beginning of his eight or more years of service to Wolsey, the physician's usefulness as an undercover operator appears to have been recognized. On 7 January 1523, Ludovico Spinelli, Venetian secretary in England, wrote to the Signory in Venice: "With regard to the Galleys ... Sebastian Falier is negotiating their release by means of a bribe through Wolsey's physician."4

There is also some evidence that Augustine at an early stage in his career was not unwilling to turn his favourable position in the Wolsey household to his personal advantage. In January 1525 Louis de Praet, imperial ambassador to England, complained to Charles $\mathrm{V}$ that all letters addressed to him as ambassador were being held up by Sir Brian Tuke, "governor of the king's posts" (i.e., postmaster-general). Such was not true, he claimed, of Jean Joachim de Passano, the representative of the French court, "who is a favorite of his [Tuke's], and knows well how to win the hearts of these people. The report is that he has lately laid out 500 gold crowns on New Year's Day in presents to the confessor, the physician and other servants of the cardinal's household ....".

Augustine's advancement in the confidence of Wolsey and in the diplomatic service was rapid. By the winter of 1526-1527, when the proposed marriage of Princess Mary to the French King, Francis I, was under negotiation, he was one of the principal representatives of the English interests. A report of the secretary of the French embassy, Claude Dodieu, establishes the physician's role as one of importance. Many

2 Th. Rymer, Foedera, Conventiones, Literae, etc., 20 vols., London, 1704-1732, XIV, 389-390; $L P$, VI, 63.

- The proximity of Venice to Padua argues for Padua as does its popularity with medical students in the sixteenth century. Several Tudor physicians, including royal staffmen Linacre, Chambre, and Edward Wotton, held Paduan medical degrees. Dr. Lucia Rossetti, archivist of the Archivio Antico dell' Universita in Padua, who has obligingly searched the archives of the early sixteenth century for me, could find no proof that Augustine had attended Padua. Unfortunately several lacunae exist in archives of that period. Augustine's name does not appear in either A. F. Dorighello, Elenco di Laureati in Padova, sec. xiv-xvii or Acta Graduum Academicorum ab Anno 1501 ad Annum 1525 (Instituto Per la Storia Dell' Università di Padova), ed. E. M. Forin, Fonti III, 1-3 (Padova, 1969-71).

- There is little doubt that the physician here mentioned was Augustine. F. Stefani, editor of the Sanuto diaries (Marino Sanuto, I Diarii di M. Sanuto, 58 vols., Venice, 1879-1902), did not identify the physician. On the other hand, Rawdon Brown (ed.), Calendar of State Papers, Venetian, III, London, 1869, 614n, seemed certain that the physician was Augustine. Sebastian Falier was master of the Venetian galleys being detained in England by order of the king, who suspected an alliance between Venice and France against England. The release of these ships was authorized a few weeks later. Ibid., III, 637.

- Calendar of Letters, Despatches, \& State Papers, Spanish, 13 vols., London, 1862-1954, III (i), p. 11. De Praet also suspected that even the cardinal himself had secretly received bribes from French agents. 


\section{Dr. Augustine, physician to Cardinal Wolsey and King Henry VIII}

details of the agreement which would eventually be formalized into the Treaty of Westminster (30 April 1527) were negotiated by Augustine acting as Wolsey's agent. It may be assumed that he was in attendance as Wolsey's personal physician when the cardinal came down with tertian fever on 16 April. $^{6}$

Subsequent to this brief encounter with fame and publicity, more than two years would elapse before Augustine again appeared in the public records. Meanwhile Wolsey was waging a losing struggle to maintain himself as the most powerful figure, save the king himself, in English politics. His enemies, chief among whom were Thomas Howard, Duke of Norfolk, and his niece, Anne Boleyn, had gained the king's ear. In the autumn of 1529 the cardinal was asked to surrender the great seal of the realm, was deprived of York House (in Westminster) and other temporalities, and was ordered to proceed to Esher, where he was to suffer further humiliations. As might have been expected, many former members of his staff-notably Thomas Cromwell, Brian Tuke and Stephen Gardiner-observing that his star was descending, went over to the enemy. Still Dr. Augustine remained ostensibly faithful to his master and was at Esher to provide medical aid during the gloomy winter of 1529-1530.

By this time Wolsey was no longer a healthy man. He was about fifty-eight years old, and the strain of public life combined with the anxieties and disappointments recently suffered were eroding his physical reserves. The attainder action, consisting of forty-four articles cataloguing his offences and taken by the House of Lords early in December, had been a fateful blow. ${ }^{7}$ Although he branded most specifications as untrue and minimized the seriousness of others, the total effect was to depress him further and aggravate his state of general debilitation. "At Christmas [1529] he fell sore sick," wrote Cavendish, "that he was likely to die."8 So serious did his illness seem that Dr. Augustine wrote to Thomas Cromwell on 19 January urging him to send Dr. William Butts, the king's own physician, as quickly as possible, for "There is danger in delay." It was also requested that a supply of "hungry leeches" be obtained from Dr. Balthasar, and that the doctor bring some vomitive electuary. If Dr. Butts were unable to come, Dr. Walter Cromer should come in his stead. In any case, no time should be lost. ${ }^{9}$ The

- $L P$., IV (ii), 3105. Dodieu's report, a lengthy one, covers the entire diplomatic transaction which continued from late February till the end of April 1527.

7 James Gairdner, 'The fall of Cardinal Wolsey', Trans. R. hist. Soc., 2nd ser., 1899, 13: $96 f$. See also $L P$., IV (iii), 6075.

${ }^{8}$ George Cavendish, Life of Cardinal Wolsey, 2nd ed., London, 1827, p. 287. Cavendish wrote his biography in 1557-1558, some twenty years after Wolsey's death. Matters of chronology and some factual details must be accepted with caution. A. F. Pollard (Wolsey, London, Longmans, 1929, p. 267) relying on the fact that Dr. Augustine summoned additional medical aid on 19 January 1530, assigned the illness to January 1530. See Br. Mus., Cotton MS., Titus B.I.f.365.

- Augustine to Cromwell, LP., IV (iii), 6151. Cavendish, probably relying on his memory, related the episode in detail. He recalled that Dr. Butts, on arriving at Esher and estimating the seriousness of the cardinal's condition, had hurriedly returned to London and reported to the king that death was imminent. A kind word or other token of affection from the king or Lady Anne (Boleyn) might, he suggested, greatly benefit the sick man. Whereupon each sent a jewel and affectionate messages to be delivered by Butts. In addition, the king despatched other members of his staff, Clement and Wotton, as well as the Scottish physician Dr. Cromer, to assist Butts and Augustine in treating Wolsey. Dr. Balthasar (or Balthasar Quersie), a native of Italy, was surgeon to Catherine of Aragon. See Cavendish, op. cit., note 8 above, pp. 287-290. For further information on the medical staff of Henry VIII see Sir Arthur S. MacNalty, Henry VIII, a difficult patient, London, Christopher Johnson, 1952, pp. 140-149. 


\section{E. A. Hammond}

combined skills of Butts and Augustine, added to those of Drs. Clement, Wotton and Cromer, representing in composite the finest medical service in Britain, soon brought the cardinal back to health.

Augustine was again pressed into semi-secret service late in January. The cardinal, whose hopes for reinstatement were revived by token gestures of favour from the king, sent him to attend the ailing Jean Joachim, recently arrived from Paris. Chapuis, the imperial ambassador, who did not completely understand Joachim's mission, wrote to his emperor on 6 February: "The said Joachim lodges at a [London] house of one of the Cardinal's servants; and soon after his arrival, the Cardinal, though unwell, sent his physician, a Venetian (De Augustinis), in whom he has much confidence, and who stayed with Joachim for four or five days." 10 In the meantime, Wolsey's health having been restored, the attacks from his enemies were resumed.

From Richmond, whither he had removed early in February, Wolsey carried on a desperate but hopeless struggle for reinstatement. Neither his overtures to the French ambassador nor his pathetic appeals to King Henry himself availed him more than a momentary delay of the sentence which had already been pronounced by the Howards. He must leave the London area and repair "to his diocese"; not to Winchester as he would have preferred, but to York, whose absentee archbishop he had been since 1514 . His objections and excuses were brushed aside. Departing Richmond on 5 April, he made his way slowly and grudgingly northward, arriving at his less-than-sumptuous palace of Southwell (Nottinghamshire) on the 28th. ${ }^{11}$ Here, with a diminished household staff, he remained until 1 September, "wrapped", as he phrased it in a letter to his king, "in misery and need on every side." 12

Dr. Augustine had of course gone north with his patron. His activities, in so far as they are traceable, suggest that he had read the omens well and was aware of the probability of the cardinal's ultimate downfall. He had maintained cordial contact with Cromwell, who, in spite of (or because of) his phenomenal rise at court between October 1529 and February 1530, had no intention of severing his lines of communication with Wolsey's household. Augustine, for his part, was a willing ally, eager to keep his fences mended. Should total calamity eventually befall the cardinal, to whom better than Cromwell might he turn for aid? At any rate, he sought Cromwell's aid in the spring of 1530. The precise nature of Cromwell's favour cannot be determined, but it was probably the matter of ushering the physician's denization papers through the maze of the chancery office. His gratitude was profound. On 10 May he wrote

\footnotetext{
10 Joaquim, fully styled Jean Joaquim de Passano, Sieur de Vaux, was usually referred to simply as de Vaux. LP., IV (iii), 6199. Wolsey was obviously uncertain as to the purpose of Joaquim's visit. He seems to have assumed that the French government would like to bring about his reinstatement, and that Joaquim was the agent employed to effect it, hence the mixed motive of extending a courtesy to the sick ambassador while placing his man in the confidence of the diplomat who might reveal his true mission. Only later did it become clearer that the French were merely assessing Wolsey's position to determine, as Pollard expressed it, "whether it was worth making an attempt ...." Pollard, op. cit., note 8 above, p. 269. The letter of Chapuis discloses incidentally the presence in London of a cousin of Dr. Augustine, a man also engaged in traffic in information. No further identification of the cousin is provided, however, See also Cal. St. Pap., Spanish, IV (i), 448-450.

11 The details of Wolsey's progress from Richmond to Cawood Castle, some ten miles from York, are to be seen in Pollard, op. cit., note 8 above, p. 275ff.

12 This letter, Wolsey to the king, written shortly after his arrival at Southwell, reflects the genuine despair which had overwhelmed him. LP., IV (iii), 6344.
} 


\section{Dr. Augustine, physician to Cardinal Wolsey and King Henry VIII}

Cromwell from Southwell: "By your servant I learned that my letters patent have been perfected in Chancery . . . . If I was obliged to you before on many accounts, I shall now be still more indebted to you, while I live, for this great benefit. I am persuaded that no man in the world except you could have conducted such an affair with success, so that I shall ever be at your service."13 The fee for naturalization in this instance was sixty-six shillings eight pence, a considerable sum for those times and one which the servant of a suddenly impoverished archbishop might have difficulty in obtaining. ${ }^{14}$ The Rymer entry identified Augustine as "Professor of Medicines, born in Venice," and lists among the privileges conferred through naturalization the right to hold church benefices with and without cure. His first preferment came soon: on 5 August 1530 he became prebendary of North Newbald in the diocese of York. ${ }^{15}$

A letter written some time in September (1530) by Dr. Edmund Bonner, Wolsey's chaplain, to Cromwell further suggests the lines of communication with the cardinal's household. Writing from Scrooby (co. Notts.), where Wolsey's entourage had tarried briefly before moving on to Cawood at the end of September, Bonner reminded Cromwell, "As you wished to make me a good Italian sometime since, by promising to lend me the 'Triumphs of Petrarch,' I beg you to send it by Mr. Augustine's servant, and specially if you have it, the Cortigiano [sic] in Italian". ${ }^{16}$

Although little of his correspondence from this period has survived, it is reasonably certain that Dr. Augustine continued to maintain his contacts with diplomatic agents and friends in London throughout the summer and autumn of 1530 . Near the end of April Wolsey had moved into Southwell, briefly occupying the residence of an archdeacon while the palace there was being made ready. There he remained until 1 September. In mid-June the imperial ambassador, Chapuis, interrupted one of his long dispatches to the emperor to insert the following:

While writing the above I have received a letter from the Cardinal's physician in which he tells me in rather obscure terms that his master [Wolsey], not knowing exactly the state of the Queen's [Catherine] affairs, cannot give any special advice upon them; that if he could get the fuller information he would give counsel and directions ...., and that it seemed to him that now was the time to take stronger measures and call in the assistance of the secular arm.... The physician did not further explain the Cardinal's meaning, and therefore I am at a loss to interpret his message and wishes. ${ }^{17}$

Although forced by circumstances to operate from the comparative isolation of central Nottinghamshire, Dr. Augustine was still able to play his role as information broker.

13 Even allowing for some effusiveness of language, it appears that Augustine and Cromwell were still fast friends. Both had served Wolsey for at least five years. It is a reasonable conjecture that their friendship dated from the days when Cromwell was a sojourner in Italy. Ibid., 6374.

${ }^{14}$ Ibid., Augustine proceeded to explain that he was momentarily short of funds with which to pay the chancery fees and requested Cromwell to hold the patents in a safe place until he could redeem them.

${ }^{15}$ The confusion concerning the date of Augustine's denization arises from the entry in Rymer (Foedera, XIV, 389-390), which assigns it to 10 May 1530. J. S. Brewer, in editing the item for the Public Record Office, discovered that it was accomplished on 24 February 22 Henry VIII (24 February 1531). It is probable that the patent was processed prior to 10 May 1530, but that its enrolment was delayed until the following February. LP, V, 232. Augustine held the prebend only briefly, resigning prior to 24 March 1531. J. Le Neve, Fasti Ecclesiae Anglicanae, Northern Province, B. Jones, comp., London, Institute of Historical Research, 1963, p. 70.

${ }^{16} L P$, IV (iii), 6346.

${ }^{17}$ Cal. St. Pap., Spanish, IV (i), 354. Letter of 15 June 1530. 


\section{E. A. Hammond}

The month of October passed quietly at Cawood Castle, recently restored to accommodate the cardinal and his staff. The winds of fortune were about to blow cold, however, and the intelligence borne by every courier increased the anxiety of the cardinal and his household. Dispatches from the south were sufficiently explicit to indicate that his interests were not being well served at court. The dissolution of his colleges seemed imminent, ${ }^{18}$ and any remaining hope for restitution to his former power was virtually destroyed. Then, on All Hallows' Day, the calm was broken with dramatic suddenness.

It is impossible to reconstruct accurately and fully the activities of Cardinal Wolsey and his physician from their arrival at Cawood Castle on 29 September 1530, till their arrest thirty-six days later. Much secrecy shrouded their actions. Many imputations of impropriety, disloyalty and even treason, based in part on rumour and hearsay, were directed at the two men. Foreign diplomats in London, eager to report the English situation to their masters on the continent, salted their dispatches with gossip about the impending doom of Wolsey and his associates. Given the sensitive nature of the Wolsey situation, it is understandable that scarcely a document bearing his signature has survived from the last five weeks of his life, although there is evidence that he was engaged in desperate moves to regain his former authority.

Early in October the cardinal had sent a gentleman from his privy chamber bearing letters to the Duke of Norfolk, then at Hampton Court. This emissary, Thomas Arundell, reported to his patron on 17 October that the messages designed to reassure Norfolk that Wolsey had no desire to return to his former office and would be content to remain in the comparative seclusion of York, had been duly delivered. Norfolk bluntly told Wolsey that Norfolk did not believe him, since he had been persuaded by others that the cardinal had every intention of reasserting his former power. Recognizing the failure of his mission, Arundell asked that he not be implicated in any way in the affair. He nevertheless closed the letter with unconvincing assurances that the Wolsey cause was not hopeless and that his colleges would be preserved. ${ }^{19}$

This letter apparently convinced Wolsey that little support would be forthcoming from London, where many of his former associates and servants had accurately read the signs and concluded that no personal gain could come from any further allegiance to the prelate. On 21 October, Thomas Cromwell wrote requesting that Wolsey provide a benefice in York for a kinsman, Dr. Karbott, concluding his letter with the halfhearted encouragement that Wolsey's welfare was a matter of official concern in London. ${ }^{20}$ Nevertheless, Wolsey determined to proceed with the installation ceremonies scheduled for 7 November in York, perhaps suspecting that his enemies at court had no intention of permitting the rites to take place. ${ }^{21}$

In the meantime, Wolsey was making his last frantic effort to gain assistance from

${ }^{18} L P$, IV (iii), 6666. William Tresham, in a letter of 7 October, tried to break the news gently to Wolsey. The colleges, one at Oxford and the other at Ipswich, had been established by the cardinal with funds derived from the suppression of several smaller religious houses.

19 LP, IV (iii), 6688.

${ }^{20} L P$, IV (iii), 6699.

21 Although Wolsey had received the temporalities of his archbishopric on 5 August 1514, other formalities, including his enthronement, had been carried out by proxy. Now, sixteen years later, his formal installation was to be marked by such splendour as his reduced circumstances would permit. See Le Neve, op. cit., note 15 above, p. 5. 


\section{Dr. Augustine, physician to Cardinal Wolsey and King Henry VIII}

Henry's opponents on the continent. Rumours were rampant that the French king, the emperor, and the Pope had been urged to take extreme measures on Wolsey's behalf. Late in November the crafty Eustace Chapuis reported to Charles V that Wolsey had requested Rome to reinstate him in his possessions, had asked France for its favour, and "was returning to his ancient pomp, and was corrupting the people." 22 A little earlier the French ambassador, De Vaux, had informed his government that "as to the Cardinal, I fear he cannot do well. They [Norfolk and Suffolk] say they have many important causes against him; and the King says he has intrigued against them, both in and out of the kingdom, and has told me where and how, and that one and perhaps more of his servants have discovered it, and have accused him." ${ }^{23}$ Whatever his private disposition with regard to Wolsey's plight it was increasingly clear that no foreign monarch was prepared to risk a serious breach with England to save a falling cardinal or even to prevent an unpopular divorce. Thus Wolsey's entreaties, however moving, availed him nothing, and he was far too experienced in statecraft and diplomacy to have misread the information which filtered in to him. Most important of all, his arch-enemies at court, the Duke of Norfolk and "the Lady" (Anne Boleyn), were relentless in their determination to destroy him. Norfolk alone could hardly have accomplished it, but on the occasions when Henry wavered and exhibited an inclination to spare the cardinal, Anne's charm rendered the royal will helpless. ${ }^{24}$

If the cardinal's activities during the month of October remain obscure, those of his physician are even more so. No one was better situated to assess the extent of Wolsey's physical deterioration nor to judge the futility of his political manoeuvres than was Dr. Augustine. Although he remained ostensibly faithful to his patron he had not neglected his London contacts, apparently aware that his position in the archbishop's household was soon to be terminated. It was presumably while serving the Wolsey cause that certain letters of his addressed to the French ambassador, De Vaux, were intercepted late in October. Augustino Scarpinello, Milanese ambassador in London, reported the incident in a letter of 2 December, stating that, although the contents of the letters were not known to him, they were presumed to contain requests for favours from the French king. ${ }^{25}$ Simultaneously, a chaplain of the cardinal's household was arrested while en route across the Channel bearing letters which Scarpinello understood to have been of little importance. There can be no doubt that all movements of Wolsey and the members of his household were closely watched by agents of Norfolk and the king.

Dr. Augustine figured in an occurrence of All Saints Day, 1530, related by Cavendish, to which much significance was attached by those who witnessed it. As the cardinal sat

$22 L P$, IV (iii), 6738.

${ }^{23}$ LP, IV (iii), 6720. Letter of 10 November 1530, written before Wolsey's arrest on 4 November had become common knowledge.

${ }^{24}$ It should be recalled that Henry, whenever he looked to his conscience, had serious misgivings about his treatment of the cardinal, to whom he owed so much of the splendour and success of his reign. It was indeed Wolsey who, as Mr. J. S. Brewer stated it, had lifted England from a third-rate kingdom of small account to an equality with the other states of Europe. (See LP, IV, Introduction, dcxxii.) On rare occasions, when Henry became impatient with the incompetence of certain ministers, his esteem for the cardinal's ability was revealed, as when he uttered to the Privy Council, "Every day I miss the Cardinal of York." Ibid., dcxx.

${ }_{25}$ Cal. St. Pap., Venetian, IV, 637. 


\section{E. A. Hammond}

at dinner attended by the more worthy members of his staff, the physician, on leaving the table, accidentally upset a heavy silver cross mounted on a staff and leaning against a drapery at the table's end near the cardinal's chair. As the cross fell one of its sharp corners struck the head of Dr. Edmund Bonner, a chaplain to Wolsey, drawing blood. Wolsey, observing the accident, was heard to remark, "malum omen". Cavendish recalled that on the following Sunday (6 November) while resting overnight at Pontefract Abbey, Wolsey had interpreted for him the meaning of the incident. The cross signified the cardinal himself; Dr. Augustine, who overthrew the cross, "he understood to be he that should accuse him, by means whereof he should be overthrown." ${ }^{26}$

Notwithstanding the incident of the falling cross, whatever its augury, the plans for the installation on 7 November were carried forward. Certain developments, such as the uncertainty of Bishop Tunstall of Durham as to whether he would attend the convocation called by Wolsey for York on the 7th (to coincide with the installation), must have provoked doubt in the cardinal's mind that he would ever become officially the archbishop of York, although he could have had no certain knowledge that his enemies in London had already determined that the installation would not take place.

By the end of October the plan for Wolsey's downfall was complete. On 1 November Sir Walter Walsh, king's messenger, left Greenwich with a commission to join the Earl of Northumberland and proceed with their respective aides and retainers to Cawood for the purpose of arresting Wolsey. They reached Cawood on the evening of 4 November and the arrest was made by Northumberland. ${ }^{27}$

On this fateful Friday of 4 November Wolsey and his physician saw each other for the last time. At the very moment when Northumberland, having been ushered into Wolsey's chambers, was awkwardly and humbly attempting to make the arrest, Sir Walter Walsh, wearing a hood to conceal his true identity, was unceremoniously-even violently-placing Dr. Augustine under arrest and branding him "traitor". ${ }^{28}$ Later that evening the physician was tied to his horse, as was the custom in transporting criminals, and secretly rushed away toward London. Upon arrival there he was taken

\footnotetext{
${ }^{26}$ Cavendish, op. cit., note 8 above, p. 342. This account suggests that Wolsey had come to distrust his physician. At this juncture Augustine had not arrived in London and his treachery with respect to Wolsey had not been perpetrated.

${ }^{27}$ Ibid., p. 342ff. The details of the arrival of the commissioners at Cawood and their encounter with the cardinal are here set forth. The day after the arrest was spent in preparation for the journey southward. The guard, with its distinguished prisoner, left Cawood on Sunday, 6 November, arriving that evening at Pontefract Abbey and lodging there for the night. Monday night was spent at Doncaster. On Tuesday the party moved on to Sheffield Park where it was received by the Earl of Shrewsbury, who had been instructed by the king to provide comfort and warm hospitality for the prelate. Here the cardinal was to remain for about a fortnight.

It is never made totally clear why the king had thus temporized with Wolsey, allowing him such an agreeable respite from his woes. It would appear that, having thwarted the installation rites at York, he was unwilling to bring the cardinal to London to face his accusers, perhaps hoping to find in time a means of sparing him and bringing him again into royal service

Suddenly, on the 22nd, however, Sir William Kingston, constable of the Tower, arrived at Sheffield to escort the prisoner to London, assuring him that the king bore him no ill will and wished only "that ye shall be able to acquit yourself against all complaints and accusations exhibited against you" (ibid., p. 376). Thus the doleful journey was resumed on 24 November only to end five days later at Leicester Abbey, where death rescued the prelate from the ultimate humiliation prepared for him by his enemies.

${ }^{28}$ Ibid., p. 348
} 


\section{Dr. Augustine, physician to Cardinal Wolsey and King Henry VIII}

directly to the Tower. ${ }^{29}$

Reports of the arrests of Wolsey and Augustine were received in diplomatic circles with shock and anxiety. Treason was a serious offence while espionage could prove embarrassing, and no one could predict the implications of the arrests should the contents of many secret dispatches be made known. Meanwhile the facts of the situation were agonizingly slow in coming to light. Most foreign agents in London had anticipated Wolsey's calamity and eagerly awaited any information that could be passed on to their respective governments. De Vaux, the French ambassador, wrote to his government on 8 November but held the letter for two days, "hoping for more news of Wolsey to include". ${ }^{30}$ On the 13th Chapuis could report to the emperor that "eight days ago the Cardinal, by the King's command, was removed from the keeping of Northumberland and placed again in the charge of Tallebot [Shrewsbury]," adding that "the Cardinal's physician, moreover, has been sent to the Tower as a traitor." 31 Two days later the Venetian ambassador, Ludovico Falier, reported the arrest of Wolsey and his physician..$^{32}$ On the 17th Scarpinello, the Milanese ambassador, reported the arrest of Wolsey and Augustine, as well as a chaplain of Wolsey's household who was on his way across the Channel "with certain letters, which are understood not to have been of much importance." 33

Before the end of November the dispatches were more substantial, due in large measure to the fact that Dr. Augustine, after a night at the Tower, had been removed to the Duke of Norfolk's town house and there, either from blandishment or coercion, had sung "the tune as they wished him". ${ }^{34}$

On 27 November Chapuis sought to bring his government abreast of events in London with a letter, both factual and speculative, summarizing the situation as he understood it. Wolsey was being brought to London but, having fallen ill on the road, had not arrived. His arrest had been effected because Anne Boleyn and her uncle, Norfolk, would be satisfied at nothing less. Wolsey had appealed to Rome for reinstatement of his former possessions and power and had implored France to lend support to his plea. The Norfolk faction had Augustine in their hands at the Duke of Norfolk's house where he was being entertained like a prince, which showed that he had told the cardinal's enemies what they wished to hear, to wit: the cardinal had solicited the Pope to excommunicate the king and lay an interdict on the kingdom unless he immediately dismissed "the Lady" from Court and treated the queen with proper respect; the cardinal hoped by such measures to cause a rising throughout the country, and in the midst of the confusion to seize the reins of government. Chapuis then disclosed his personal anxiety:

29 Cal. St. Pap., Spanish, IV (i), 492. Chapuis to Charles V, 13 November 1530.

${ }^{30} L P$, IV (iii), 6720.

31 Cal. St. Pap., Spanish, IV (i), 492.

32 Cal. St. Pap., Venetian, IV, 631.

${ }^{33}$ Ibid., IV, 632.

${ }^{34} L P$, IV (iii), 6738. The Duke of Norfolk's house was situated at Broken Wharf in the parish of St. Mary Somerset on the south side of Upper Thames Street, opposite the parish church. The earliest structure, built in the thirteenth century by the Bigod family, came into the possession of the Norfolk earls (later dukes) in 1316 and remained in their hands, except for a few brief intervals, until Elizabethan times. See 'Historical notes of medieval London houses', London Topographical Record, 1916, 10: 77-78. See also Henry A. Harben, A dictionary of London, London, Herbert Jenkins, 1918, p. 110. 


\section{E. A. Hammond}

I think the physician must have declared he had no intelligence with me; otherwise the Duke [Norfolk], who is a bad dissembler, would have said something about it. They might have also summoned the person who was the go-between, to whom the physician wrote, and who sent him the answers; but up to this time not a word has been said about it. Were the physician to say all that has passed between us he could not do anything to impugn me..5

A dispatch of 2 December, Scarpinello to Francisco Sforza, Duke of Milan, contained much the same information and, in addition, included the news of Wolsey's death at Leicester. He wrote, "It is supposed that his [Augustine's] deposition justified the capture of the Cardinal, and it certainly may be supposed that his Majesty would not have acted thus without strong causes." 36

The above letters and some others less informative suggest certain conclusions. First, Augustine had been ostensibly faithful to Wolsey until the night of the arrests. Second, he had employed his knowledge and skills to the best of his ability in preserving the health of the cardinal. Third, he had also engaged in a sort of underground diplomacy or espionage which, if fully disclosed, would implicate more than one foreign agent in London. Fourth, realizing more completely than anyone else that the cardinal's course was about run, he had provided Norfolk with a deposition which would have been utterly damaging to Wolsey (had he lived a little longer) and which had prompted the orders sending Sir William Kingston to Sheffield Park on or about 19 November to fetch the cardinal to London to face his accusers. ${ }^{37}$

The following item, recorded at Hampton Court on 11 December 1530, just twelve days after Wolsey's death, and now in the Public Record Office, leaves little doubt about the deposition.

A recognisance of Mr. Doctor De Augustinis, Venetian, in the sum of $£ 100$, to be paid to the use of our sovereign lord the King at Christmas next; on condition that if he keep secret all such matter as is mentioned in a book written with his own hand concerning the late cardinal of York (Wolsey), and presented by him to my lord of Norfolk, president of the Council, this recognisance shall be void; otherwise it is to stand in full force. ${ }^{38}$

In other words, the physician was munificently bribed to maintain strict silence concerning the contents of the deposition as well as the circumstances under which it had been obtained. Now that death had removed the troublesome cardinal the deposition was no longer necessary for his prosecution. It was therefore judged wiser to suppress its contents and the chicanery employed in the plot to ruin Wolsey than to publicize the matter and risk unfavourable public reaction.

In spite of these precautions the general contents of the deposition were soon made known and much discussed among those close to the government. Augustino Scarpinello's letter to Francisco Sforza, dated 16 December, offered two explanations for the arrest of Wolsey at Sheffield: the deposition of Dr. Augustine, and certain letters and papers of the cardinal which had been intercepted by agents assigned to

ss $L P$, IV (iii), 6738.

${ }^{36}$ Cal. St. Pap., Venetian, IV, 637.

${ }^{37}$ On 27 November Chapuis wrote: "Eight days ago the King gave orders for the Cardinal to be brought here." $L P$, IV (iii), 6738.

${ }^{88} L P$, IV (iii), 6763. The calendared version cited here provides the details of the original document except for the stipulation that Augustine "will faithfully and sanely behave against our said sovereign lord as a true subject ought to do, and beside that kepe secrete froam any man, ...". 


\section{Dr. Augustine, physician to Cardinal Wolsey and King Henry VIII}

keep him under surveillance. Scarpinello concluded that, having been reduced to desperate circumstances, Wolsey had little choice but to attempt to recover his lost properties and power by enlisting foreign support. In his attempts to bargain he was said to have offered to both the king of France and the Pope certain concessions which would have been only "slightly advantageous or satisfactory to his own sovereign." It was rumoured, said Scarpinello, that he proposed on his return to power, "to cancel the debts due from France to England." He reminded the Pope of how important his own restoration was to the preservation of supreme papal authority in ecclesiastical affairs in England. Then, metaphorically, Scarpinello dismissed the Wolsey issue: "But the serpent being dead his poison also died. He has at length disappeared, nor is there any longer remembrance of him." 39

What is to be said of Augustine's role in the downfall of his employer? There is no evidence that, prior to the journey northward in the summer of 1530 , the physician had been less than loyal. It appears, however, that he did maintain his contacts with former London associates during that summer and into the autumn, but such correspondence relative thereto has not survived. There can be little doubt that in the month of October he was one of Wolsey's most reliable agents, assisting in the attempts to enlist foreign support. Still, as Pollard has observed, there is no evidence that Augustine was in any way responsible for the initial arrest of the cardinal on 4 November. Quite the contrary, however, for the arrest at Sheffield Park about the 19th, in which case the evidence strongly suggests that, in his role as informer to the Duke of Norfolk, he provided the final proof needed for a charge of treason. In so doing his reputation seems not to have suffered and, as will be shown, he moved into the next phase of his career unsullied by his treachery.

\section{PHYSICIAN AND SPY}

The last traces of Augustine's association with Wolsey were discovered by surveyors at Cawood Castle in October 1531. Their inventory of the room known as Augustine's chamber lists only a "chest locked wherein be divers court rolls of accounts" and other papers "lying upon a bench in the garret above", and a few additional shabby remains such as a "bedstead without a bottom" and two images upon a post. Such personal effects as he had been forced to abandon at the time of his arrest a year earlier had probably fallen into the hands of household servants or local scavengers. ${ }^{40}$

The developments of November 1530, especially the cardinal's death, had come with such suddenness as to catch his enemies unprepared. The anticipated complications and consequences of a trial for treason had been obviated. And yet a rigid surveillance over the activities of all who had served Wolsey was deemed necessary. How better to justify the illegal procedures to be employed against Queen Catherine than to discover treasonous behaviour among those defending her cause? The ever-alert Chapuis informed his Emperor on 1 March 1531, that all letters from Rome were being intercepted at Calais. "It is thought," he added, "that in them there has been some disclosure of intelligence of the late Cardinal's physician, who since the receipt of the said letters has been kept in a chamber in the Duke of Norfolk's lodgings, for what reason

s9 Cal. St. Pap., Milanese, I, 838.

${ }^{40}$ P.R.O., SC 11/766. 


\section{E. A. Hammond}

is not yet known."41 Beyond this vague note no record of the activities of the physician, during those weeks at the Norfolk house has survived, nor is the date of his release known. He had probably been set free as early as mid-February, as will subsequently be shown. In mid-March he resigned his prebend of North Newbald (in York Cathedral), which he had held for slightly more than seven months, the benefice having passed into the king's hands upon Wolsey's death. ${ }^{42}$

For a brief period, probably while he was still in Norfolk's custody, Dr. Augustine resumed the practice of medicine. Among his patients was Dorothy, Countess of Sussex, whose bedside he declined to abandon in spite of an urgent call from Lady Anne, wife of Sir John Russell (later 1st Earl of Bedford), who lay ill at Chenies, her country home in Buckinghamshire. From a letter, Richard Manchester to Lady Russell, undated but probably written in February, it is clear that the physician was again dwelling at his own London residence. ${ }^{48}$ The incidental information relating to the medical profession in London contained in this letter warrants citing it (in calendar form) at this point.

On receipt of Lady Russell's request for medical assistance, he [Manchester] had gone to Dr. Augustine's house, only to find him away. He then went to Dr. Mychalas' house, who had left for Kent. He then went to Dr. Cromer, one of London's most eminent physicians, who had so many patients he was unable to leave the city. Finally Manchester returned to Augustine's to find him at home this time. But the physician was unwilling to leave the Countess of Sussex to make the trip into Buckinghamshire to see Lady Russell. In desperation, the priest sought help from Mr. John, an apothecary, who agreed to do such service as he was able, "but only after a physician hath made the bill."

But Augustine's experience under Wolsey, his proficiency in languages, and his skill in diplomatic intelligence were far too valuable to be utilized at the bedsides of even the noblest of English women. Besides, his debt to Norfolk must be paid, and on the duke's terms. So the first of March found him in Flanders awaiting the arrival of Emperor Charles $V$ and ready to do the bidding of his English patrons.

In 1531 England was without a resident ambassador at the imperial court, although Stephen Vaughan was the king's official agent in the Netherlands. Due to the far-flung character of his domains, the court of Charles was more peripatetic than most, and foreign agents in attendance were expected to be prepared for sudden moves, equipped to finance their missions for extended periods while they waited for bank drafts or letters of credit to overtake them. After spending the greater part of 1530 among his Hapsburg possessions, much of the time at the Diet of Augsburg engaged in the tedious business of the Protestant heresy, Charles moved on to Aachen for the coronation on 5 January of his brother, Ferdinand, as "King of the Romans", or emperor designate. Before the end of January he had arrived in the Netherlands, where he would remain for a year.

$1 L P, V, 120$.

42 Le Neve, op. cit., note 15 above, p. 70. A letter patent of 16 March presented George Folbery to the prebend, vice Augustine de Augustinis, M.D., resigned. See also LP, V, 166. (p. 79).

a Richard Manchester, priest of Savoy, to Lady Russell, LP, V, 233. The editor, J. S. Brewer, assigned this letter to May 1531, but it was obviously written earlier since, as will be shown, Augustine was already on the Continent by early March. Brewer, in his general introduction to these "Letters and Papers", warned his readers against blind reliance upon the dates which he assigned to undated documents. 


\section{Dr. Augustine, physician to Cardinal Wolsey and King Henry VIII}

Even before the emperor had come to Ghent on 3 or 4 March, Dr. Augustine had established contact with the chief imperial councillor, Nicholas Perronet, Lord Granvelle, newly appointed to replace the deceased Mercurio Gattinara, Charles' most capable chancellor. ${ }^{44}$ His letter of 3 June 1531, to Norfolk, deferential in tone, indicates that he was more in the employ of the duke than of the king. He spoke of previous letters, hitherto unacknowledged by Norfolk, and expressed uncertainty as to whether he should continue his mission. He closed, however, with the assurance that he would never enter the service of another without giving Norfolk proper notice. The inference is clear that such a choice had at least entered his mind..$^{45}$

An examination of Augustine's associations and actions at the court of Charles leaves no doubt that he was England's principal, though semi-official, agent in residence. ${ }^{46} \mathrm{He}$ was much in the presence of the emperor himself, not to mention the stream of worthies who had business with Charles. If we may trust his own account, he had, in his initial conferences with Granvelle, established himself as trustworthy and had gained the confidence of those close to Charles. He had assured Granvelle that the continuation of amicable relations between England and the Empire was his prime desire. Near the end of April he was invited to the imperial chamber for an audience which, he reported proudly, had lasted for an hour. Both Charles and Granvelle were eager for the authentic word on the death of Wolsey. "Was he poisoned?" they had wanted to know. "Not at all," the physician replied, "but [death came] from a tremor of the heart and [an excess of] black bile, and perhaps from anguish of soul brought on a long time ago."47

Augustine's letter touched on many of the vital issues of the moment. Charles' attitude toward Henry he estimated to be friendly, but not so steadfastly so as to withstand further onslaughts upon the rights of Queen Catherine. Henry must realize what the emperor owed to the blood of Spain. Other burning questions put to Augustine related to the commerce of England and Spain, the threat of the Turks, and the spread of Lutheranism to England. To these and other enquiries the physician responded on his own responsibility, he said, "as I had no commission." On the matter of spreading Lutheranism he had informed the emperor that heretical men and books were indeed making their way from the Netherlands into England, but that no one was more diligent than Henry himself in ferreting them out and maintaining a constant defence of the faith. Augustine had also put to rest a rumour, which had delighted certain cardinals of his acquaintance, that Norfolk and Lady Anne were currently at odds and that drastic changes in the English government were imminent. He reported also a recent conversation with Louis de Praet, Charles's chamberlain, on the death of Wolsey. "I can hardly believe the hatred of this man for the Cardinal, even though he is now dead." But not to be overlooked as an indication of the status which the physician temporarily enjoyed is this incidental statement: "I attend his Majesty every day at dinner."

4 On 3 March the Mantuan ambassador wrote to the Duke of Mantua: [The Emperor] departed "Brussils this day at noon for Ghent." Cal. St. Pap., Venetian, IV, 657.

${ }^{25} L P, V, 283$. Augustine to Norfolk, dated at Ghent.

46 Sir Thomas Eliot, England's next ambassador to the imperial court, was appointed in the summer of 1531 , but only assumed his duties in early October. $L P, V, 416$, App. 15.

17 Ibid., V, 283. 


\section{E. A. Hammond}

Augustine closed his letter with an obsequious plea, one which was to be repeated dozens of times in subsequent communications. As one who must live by his wits, he was acutely aware of the political uncertainties of life at the English court. He had no intention of permitting himself to be forgotten. He wrote: "I beg you to turn your eyes of liberality and mercy upon me, and have some regard to my poverty, so that if I cannot by active service, I may at least by my prayers ask God to preserve his Majesty, and send him his wishes, and likewise preserve the happy state of your Excellency, and not suffer it to be deprived of your rising family ...". He then reminded Norfolk that he had received no advantage in his present mission and begged to be regarded as a dependent, declaring his attachment to his lordship for his singular endowment of mind and body.

For more than two years Augustine remained close to the court of the emperor, following the imperial entourage wherever the responsibilities or whims of Charles might lead. The first year was passed in the Low Countries, much of it in Brussels where the court was established. After many delays, prompted perhaps by his reluctance to enter the sea of troubles which awaited him in Germany, Charles finally made his departure on 15 January 1532, sojourning briefly in Aix-la-Chapelle, then moving on up the Rhine, and across to Regensberg on the Danube, where he was to remain for several months. His ill health-a severe attack of gout-kept him in Regensberg through the summer of 1532, and only in late September did he arrive in Vienna. When that city suffered a plague epidemic to which several members of the imperial household fell victim, Charles quickly moved southward into Italy and by midNovember had established his court in Bologna. ${ }^{48}$

So for the first seven or eight months of his service on the continent Augustine was England's sole agent at the imperial court, ${ }^{49}$ Stephen Vaughan, England's envoy to the Low Countries, was occasionally present, but his preoccupation with matters of trade kept him much in Bruges, Ghent and especially Antwerp, where England maintained a commercial office. Besides, as the heresy spread among the urban population of the Low Countries, Vaughan was under increasing pressure to keep a vigilant eye on religious developments and report them to his government in London. ${ }^{50}$ Thus did heavy responsibility devolve upon Augustine.

At some undetermined date in 1531, Augustine ceased to make his reports to Norfolk and made them instead to Thomas Cromwell, whose phenomenal rise at the English court had brought him into the Privy Council during that year and into the role of Henry's chief minister shortly thereafter. It was to be expected that Cromwell would turn to his former friend and colleague from the Wolsey days for the kind of service that the physician was so well equipped to provide. The physician's reports,

\footnotetext{
48 Among the victims was Waldesius, Charles's chief secretary. Ibid., V, 1449, Thos. Cranmer to Henry VIII, 20 October 1532. The imperial retinue travelled to Italy by way of Villach.

" Sir Thomas Eliot, formerly of Wolsey's household, was reluctant to accept the diplomatic post. He was charged with the impossible task of obtaining Charles's assent to the divorce, although there is some evidence that he himself was sympathetic to Queen Catherine. His letters to friends in England contain complaints that his services were unappreciated and inadequately funded. After numerous requests, he was relieved of his commission early in 1532, his official explanation being that his wife had insisted upon it. LP, V, App. 15. See also ibid., V, 1077 and 733.

${ }^{50}$ Ibid., V, 574, Vaughan to Cromwell, 9 December 1531, from Antwerp.
} 


\section{Dr. Augustine, physician to Cardinal Wolsey and King Henry VIII}

filled with information on current international issues and often spiced with petty gossip gleaned from other foreign agents, continued until March 1533, when Charles left Alessandria for his long-delayed return to Spain and Augustine began his overland journey back to England. ${ }^{.1}$

His experience in Wolsey's household had brought Dr. Augustine into the company of England's most celebrated religious and political personages and had whetted his fine Italian sensibilities to a keen awareness of the requirements of the role he was later to play. By 1531, he was without doubt a man of the world, not easily intimidated or overawed by the clever or powerful who had business at the court of Emperor Charles. Yet he could not conceal his gratification at being summoned for consultation and information or being the first to report international intrigue to his English employers. Augustine's mission was often difficult and exasperating, however, sometimes because English interests ran counter to those of the Empire, sometimes simply because his mission was inadequately funded. Having observed at close range the vagaries and vicissitudes in the life of a public servant, he was constantly alert to changes in political winds which could suddenly blow him into disfavour.

The year 1532 was a vexatious one for Augustine. Thomas Cranmer replaced Sir Thomas Eliot as England's ambassador at the imperial court, arriving in Regensberg about the middle of March, some two weeks after the arrival of the imperial party. ${ }^{52}$ The physician appeared less than delighted with the new ambassador, who had not been a member of the old Wolsey circle. He tersely reported to Cromwell on $21 \mathrm{March}$, "the English ambassador arrived a few days ago. He has not yet seen the Emperor, who suffers a foot injury from falling from his horse." Then in his letter of April he wrote: "I've had a long friendship with Sir Thomas Elliot ... Elliot has often promised to use his influence with you on my behalf. This he did on the last occasion when he left this court, to the great regret of all." 53

Augustine was beginning to suspect that Cromwell was forgetting him. There followed a series of bitter complaints. His 21 March letter had begun, "On leaving Brussels I resolved to write you no more; it's a waste of time, but my poverty forces me once more to beseech your favor." He then reminded the Privy Councillor of his usefulness to the English court, of their long friendship dating from the Wolsey days, and concluded with a demand for the next suitable benefice which should fall vacant,

\footnotetext{
${ }^{51}$ Augustine's correspondence during these two years was irregular, its frequency having been determined, it would seem, as much by the availability of reliable couriers as by the urgency of the matter at hand. Many of his letters were cast in the code provided by his government while some were written in his own Italian dialect and entrusted to Italian agents to translate and deliver. E.g., on 14 October 1531, Peter de Bardi of the well-known merchant and banking family, himself a denizen of London, delivered to Cromwell translations of letters from Augustine bearing the date 7 October. $L P, V, 474$. Since many dispatches referred to in the extant correspondence have not survived, we must conclude that some were so sensitive as to demand immediate destruction, while others were probably destroyed in the Ashburnham House fire of 23 October 1731, which consumed a portion of the Cottonian manuscripts. I have examined all Augustine letters presently in the Cottonian collection; while some survived undamaged, a few were so badly seared or mutilated as to render them useless in spite of commendable efforts to restore them.

"s2 Although Cranmer's commission had been issued on 24 January he had been charged with other minor duties such as consulting the universities along his route on the divorce question. Chapuis to Charles V, 5 February 1532. Ibid., V, 773.

ss Ibid., V, 910. Augustine to Cromwell.
} 


\section{E. A. Hammond}

or, in lieu of that, an immediate gift of twenty pounds. He would, he said, have appealed to Norfolk and the Bishop of Winchester, Stephen Gardiner, but he judged that that too would have been a waste of time.

A month later Augustine was again expostulating with Cromwell for his continued silence. He reminded Cromwell that in a wealthy kingdom such as England it was preposterous to claim that no benefice had yet fallen vacant. He expressed dismay that Eliot, then back in England, had done nothing on his behalf, in spite of solemn promises made on his departure from Regensberg. ${ }^{54}$ Another dispatch even more acrimonious, was forthcoming on 16 May. He wrote: "If you were as solicitous in my interests as I in yours, my business would certainly have been done long ago, and I would not have troubled you with the urgency of my letters. But you in your great prosperity neither see nor imagine my necessity." ${ }^{55} \mathrm{He}$ then likened Cromwell to their late master (Wolsey) who, said Augustine, was hated for his procrastination and for his many words without deeds. "I hope you will not imitate him in this, but rather imitate yourself, an excellent man, observant of promises, ready to do a kindness ...."

The early summer of 1532 found Augustine in Nurnberg and Vienna on undisclosed missions. Upon his return to Regensberg, probably in early July, he was relieved to find a stipend of forty nobles awaiting him at the banking house of Frescobaldi. In his letter to Cromwell on 22 July he expressed thanks but reminded him that the amount was too little and too late, the money having been spent before it arrived. Furthermore he had expected that his pension, due on St. John's Day (24 June), would have been included. Please send it! Augustine then went on to express his apprehension that he might be out of favour with Norfolk and urged Cromwell to mediate for him. He closed with the announcement that within a fortnight he would accompany Cardinal Campeggio into Italy, eventually going to Rome. ${ }^{56}$ The departure of the cardinal's retinue was delayed, however. Augustine was still in Regensberg on 11 August, when he wrote that he would be departing on 19 August. ${ }^{57}$

The physician did not cease to make his needs and wishes known in London. Again on 28 July he begged Cromwell to provide a suitable benefice and to remind the king that his stipends must not be overlooked. The letter of this date also contains a vague reference to the efforts of the French ambassador to England, Giles de la Pommeraye, to bring Augustine's cause to the attention of King Henry, an enterprise to which Norfolk had apparently pledged his support. ${ }^{58}$

In spite of the frequent and importunate demands, the payments were irregular and in many instances long delayed. At Christmas his plight became even more desperate. Writing from Bologna on 24 December, he reproved Cromwell for failure to respond to letters, implying that promises made by the king himself were not to

\footnotetext{
s4 Ibid., V, 1027.

ss Ibid.

ce Ibid., V, 1188. Augustine was at this time serving in the dual capacity of physician to the cardinal and diplomatic representative of the English crown. Lorenzo, Cardinal Campeggio, was one of several Italians holding benefices in England. He had been provided with the see of Salisbury on 2 December 1524, and enthroned by proxy on 25 January 1525. Although he was out of favour at the English court by late 1532, he was not deprived of his benefice until 21 March 1534. Le Neve, op cit., note 15 above, III, Salisbury, J. M. Horn (comp.), London, 1962, p. 3.

${ }^{67} L P, \mathrm{~V}, 1223$. Augustine to Norfolk.

ss Ibid., V, 1197.
} 


\section{Dr. Augustine, physician to Cardinal Wolsey and King Henry VIII}

be trusted. ${ }^{59}$ Three days later he wrote, "I am starving and have never passed a more gloomy day than when, in the mass for Christmas Day, I was compelled to remain without food and drink for many hours." ${ }^{\circ 0}$ His situation had worsened by early January when he bitterly complained of his poverty, saying that not even the Frescobaldi bankers would come to his rescue. ${ }^{61}$ His periodic remonstrations with Cromwell, forwarded on 13 February, closed with a threat to return to England by the end of the month should financial aid not be immediately forthcoming. ${ }^{62} \mathrm{~A}$ portion of the letter bears citing at this point:

I have written to you since leaving Germany so frequently that it is superfluous to recapitulate; but it may be my letters were late in reaching you, either by reason of my frequent moving, or by the negligence of the messengers. It is true that I could have written oftener, but I saw you had grown cool about my business; and as your purpose is not very clear to me, I may well continue to write in ambiguous language myself, that I may not displease you. I beg you will cause my compensation, which the king promised me, to be paid to the Sieur De la Pomeray; for it is not likely that in so rich a kingdom something has not fallen that might suit me." Also that you will pay Frescobaldi those $£ 20$ due to him at the terms of St. John Baptist so long ago, that I may at least live till I am provided for, and serve you in this Court.

Augustine's correspondence from the continent for the two years of his sojourn there constitutes a valuable chronicle of current military, political and ecclesiastical events. Two developments overshadow all others. First, there was the threat of a second Turkish invasion of the Hapsburg lands, the first having been repelled in 1529 at the very gates of Vienna. But more intriguing at the English court was the progress of Lutheranism and the disaffection of many of the German princes to the cause of the reformers. His periodic reports on the matters, interspersed with choice bits of international gossip, make up the substance of the physician's letters. ${ }^{64}$

Although Augustine's continental mission was essentially diplomatic in nature, it is nevertheless disappointing that his dispatches yield so little medical information. For obvious reasons he did report the various infirmities of Emperor Charles, who shortly after his arrival in Regensberg had fallen from his horse and sustained a leg injury which was slow to heal. Augustine reported that the inflammation had turned to erysipelas. A little later (16 May 1532) he mentioned that the impostume (abscess) in the emperor's leg was restricting his movements. Two months later, after leaving a spa to which he had repaired for the baths, the emperor had come down with a fever, which it was feared might bring on a return of the erysipelas. Charles' attendants had blamed the fever on the master of the baths who had ill-advisedly fed him "the flesh of wild swine and other dry meats." 65

In the summer of 1532 Augustine joined the household of Cardinal Campeggio in the capacity of physician. If prompted by considerations of financial security, he was probably disappointed. It is more likely that he weighed the advantages of the

so Ibid., V, 1657.

0 Ibid., V, 1667.

1 Ibid., VI, 22. Augustine to Cromwell.

62 Ibid., VI, 156.

os Augustine was probably unaware that de la Pommeraye had been replaced in November by Antoine de Montpezant as ambassador to England.

of Here again several letters seem to be missing. The extensive precautions taken by diplomats for assuring secrecy indicate that the problem of security was a troublesome one.

GS $L P, V, 1223$. 


\section{E. A. Hammond}

association and concluded that his service to the cardinal would bring him into close and frequent contact with both emperor and Pope. He first wrote of the decision on 22 July: "Will go with Campeggio into Italy in the beginning of August, and afterwards to Rome, where, I think, I can do good to your cause." ${ }^{66}$ Six days later, once more to Cromwell, he explained that he and Campeggio were delaying their departure pending the arrival of the Cardinal de Medicis [Hippolitus], who would accompany them. He assured Cromwell that he would always devote himself to the interests of England. ${ }^{67}$

Once in Bologna, Campeggio and Augustine had to bide their time until emperor and Pope arrived. ${ }^{68}$ Neither seemed eager to get to Bologna, the Pope having left Rome on 18 November to arrive in Bologna on 7 December. Charles had chosen to loiter in Mantua for some three weeks before moving on to Ferrara and Bologna, arriving at the latter city on 13 December. ${ }^{69}$ Ambassadors, legates and their staffs, cardinals and others had gathered for the historic conference. Augustine, as a ranking member of Campeggio's party, was privy to many of the proceedings. He reported the meeting of a welcoming party of cardinals with the emperor seven miles north of the city. He was impressed by the fact that when the emperor knelt to kiss the toe of the Pope, the pontiff declined to permit such an act of obeisance. It was with some pride that he wrote, "When he [the emperor] entered the church, and saw Campeggio in the throng, he turned some steps out of the way to embrace him, and asked after his health." ${ }^{70}$ On the same day Nicholas Hawkins, Archdeacon of Ely, and recent replacement for Thomas Cranmer as ambassador to the imperial court, wrote to Henry VIII: "The Emperour hath given Campegius a Bischoprike, and at his cumming now to Bononi [Bologna], came to him sitting emong the Cardinals, and did him greate honour and reverence, as Augustine his Physicien schowid me. ..."11

Augustine's association with Campeggio, however, was not altogether propitious. By 1532 the cardinal, then papal legate to the emperor, had become suspect at the English court. It was generally known that he had refused to press for the divorce either at the legatine court over which he and Wolsey had presided in London in 1529 or upon his return to Italy. Even though he still held the rich bishopric of Salisbury-Henry was not yet ready to deprive him-the English king was aware that his interests in Rome were not well served by a prelate who himself was a possible candidate for the papal throne. ${ }^{72} \mathrm{It}$ is doubtful, therefore that by attaching himself to

${ }^{B 8}$ Ibid., V, 1188. Augustine to Cromwell, dated at Regensberg.

${ }^{67}$ Ibid., 1197. The itinerary of Campeggio and Augustine took them through the Brenner Pass to Trent and thence to Venice. They arrived in Bologna prior to 12 October, the date of Augustine's first known communication from Italy. See also ibid., V, 1413.

${ }^{68}$ Ibid., V, 1431.

${ }^{60}$ Ibid., V, 1657.

${ }^{70}$ Ibid.

${ }^{71}$ State Papers (Henry VIII), vol VII, London, 1849, p. 405. This letter establishes the relationship of Augustine to Compeggio.

${ }^{72} L P$, V, 886. Henry VIII to his agents in Rome (Bishop Ghinucci, William Benet and Gregory Casale), 21 March 1532. Here Henry commanded that the office of Protector (of the English interests at the papal curia) be offered to either Cardinal Farnese, Cardinal de Monte or Cardinal Trani "It is more necessary," he said, "since it is certain that Campeggio is to be with the Emperor and the Pope." Concern that Campeggio might become Pope was expressed in another letter of the same date, addressed to Benet and Casale. Ibid., V, 887. 


\section{Dr. Augustine, physician to Cardinal Wolsey and King Henry VIII}

the household of Campeggio the physician was advancing his own cause. This conceivably accounts for the neglect on the part of King Henry and Cromwell of which he so frequently complained.

Upon the departure of Emperor Charles from Bologna on 28 February 1533, it would appear that Augustine bade farewell to Campeggio, who remained with the Pope in Bologna until the departure of the papal group on 10 March. The imperial party had been in Milan only briefly when it was announced that it would soon be moving on to Alessandria en route to Genoa. This was the signal for the diplomatic corps to hurry to Alessandria to procure lodgings. Augustine made the journey, which took them through Pavia, in the company of the French ambassador, Claude Dodieu, Sieur de Vely, arriving in Alessandria on 17 March. His letter to Cromwell on the 22nd, a most informative one, told of the devastation wrought in northern Italy in the recent wars, included gossip about proposed royal marriages, and reported his lengthy conversations with the Portuguese ambassador on the matter of Portuguese explorations in India and elsewhere. He also explained the delay of Charles's arrival in Alessandria as having resulted from his decision to tarry for a few days at Viglevone for hunting and bathing, "the water for which was brought from Monferrat, not far hence." "73 The emperor was said still to be suffering from the erysipelas which had troubled him in Regensberg.

The emperor departed Alessandria for Genoa on 26 March. Augustine and the English ambassador left a day or so later, travelling together as far as Saluzzo. There they were entertained for two days by the Marquis of Saluzzo at his nearby castle of Ravelli. From there Hawkins took the land route into Spain, while the physician moved on through Savoy and arrived in Lyons on 7 April. There he rejoined the retinue of De Vely, the French ambassador, and travelled in his company to the town of Roanne on the Loire, thence by boat down the river to La Charite, ${ }^{74}$ where he apparently spent Easter.

No record remains to detail the last portion of Augustine's journey back to London. It may be assumed that there were no further delays and that he was once more in London well before the end of April. It may also be assumed that his English masters, King Henry and Cromwell, were pleased with his service, for on 1 May he was secretly dispatched to Rome "in great diligence" by the king. Chapius, in reporting the matter to the emperor on 10 May, could only say, "I know not what about."75

As for the purpose of the physician's secret mission, one may reasonably conjecture that it had to do with Henry's plans to declare publicly the validity of his marriage

78 Ibid., VI, 261. The imperial party arrived in Alessandria on 21 March. Viglevone, or Vigevano, lies some 30 kilometres south of Milan, while Montferrat (Monferrato) is a region located for the most part in the province of Alessandria.

74 Ibid., VI, 335. This letter, Augustine to Cromwell, dated at La Charité on 12 April, was his first since leaving Alessandria. Easter fell on 13 April this year (1533).

${ }^{75}$ Ibid., VI, 465. The agent is here designated only as "the nephew of the Auditor of the Chamber." The auditor was still Ghinucci, and the nephew was almost certainly Augustine, although another nephew, Andreas Ghinucci, is known to have been in the service of the bishop in 1530. Ibid., V, pp. 324-325. It is quite unlikely that this man was sufficiently skilful to have been entrusted with a mission from the king to Pope Clement. Furthermore, there is a letter, Ghinucci to Norfolk, dated at Rome on 26 May 1533, requesting that favour (credence) be given "for my nephew, Augustin." This was probably written while Augustine was in Rome. 


\section{E. A. Hammond}

to Anne which had occurred in January, and his further plans for her coronation before the end of May. The Pope was known to be floundering in indecision as to what course he should pursue in the marriage matter, while it was equally well known that Charles V and others were relying on him to salvage some dignity and honour for Queen Catherine. It seemed important for Henry to communicate directly with the Pope before the latter should otherwise receive word of the coronation of Anne on 29 May. Augustine, an adept diplomat and recently in the Pope's presence at Bologna, was a likely messenger. The success of the mission may be judged by the munificence of the reward- $\$ 100$ - bestowed upon Dr. Augustine in June. ${ }^{76}$

The movements of Augustine from about June of 1533 until the following April remain obscure, although there are occasional indications that he remained in the service of Cromwell and the king. His name occurs now and then in lists of "remembrances" (memoranda) kept by Cromwell, or in postscripts to official dispatches. For example, Nicholas Hawkins, writing from the imperial court in Almunia (Spain) to Cromwell, urged the councillor to "continue your favor to Augustine."

April found Dr. Augustine a prisoner in the Tower of London. The circumstances surrounding his incarceration remain a mystery. Even Chapuis, whose letters to the emperor are a treasury of information and rumour on affairs of the English court, made no mention of the imprisonment. One may suggest tentatively, however, that it was the work of Norfolk, who was responsible for the confinement of several persons known to be sympathetic to the cause of Queen Catherine and Princess Mary. Prominent among them was Lord Dacre, victim of the wrath of Anne Boleyn and Norfolk. Augustine's offence is not stated, but his lengthy association with Cardinal Campeggio, not to mention his kinship to Bishop Ghinucci, would have rendered him suspect among Anne and her friends. It is doubtful that the king himself had ordered the imprisonment. About mid-April no less a person than Sir William Poulet (Paulet), Comptroller of the Royal Household, solicited Cromwell's aid in the relief of the the physician. "Be good to Mr. Augustyn that he may be relieved of his charge," he wrote. ${ }^{78}$

Augustine's own plea to Cromwell on 2 May leaves little doubt as to Norfolk's implication. His letter, written at the Tower on 2 May 1534, acknowledged Cromwell's intercession with the king, who had been persuaded to lessen the rigours of his confinement. He was weary, he said, of life itself and could find solace only in sacred literature. Could Cromwell possibly mitigate the displeasure of the Duke of Norfolk towards him? "I have been punished almost to death, but what advantage would the Duke gain by my death?" It would indeed become the duke to "pardon my fault, if the declaration of my opinion be a fault, when I was moved to it not by hatred but by zeal for the common weal. But if he should decline to grant this pardon to myself, perhaps he will do it for the King or for you."79

There appears to be no means of determining the precise nature of Augustine's offensive remarks, but given the issues and the political climate of the moment, it

\footnotetext{
70 Ibid., VI, 717. From the accounts of Cromwell, 29 September 1532- 28 June 1533.

"7 Ibid., VI, 1010. 21 August 1533.

78 Ibid., VII, 529.

70 Ibid., VII, 599.
} 


\section{Dr. Augustine, physician to Cardinal Wolsey and King Henry VIII}

may be surmised that they related to the determination of Anne Boleyn, abetted by her uncle, Norfolk, to complete the humiliation of Queen Catherine and Princess Mary by stripping them of their royal titles, their household comforts and their freedom of movement, and simultaneously, to secure for herself and her daughter the titles of queen and princess respectively. At any rate, there can be no doubt that it was Norfolk and not the king who had taken umbrage.

Augustine's release was soon accomplished, but his subsequent activities are difficult to follow. He apparently resumed the practice of medicine while he waited for the political turbulence of 1534-1535 to abate. Evidence points to association on his part with two eminent persons then known to have been out of favour at court-William, Lord Sandys, long-time member of the king's staff, and Sir Thomas Eliot, diplomat and author. Late in 1534 Eliot had come under suspicion for having in his possession one of the prohibited sermons of John Fisher, Bishop of Rochester. From his rural abode at Combe, Oxfordshire, he wrote to Cromwell proclaiming his innocence and asking advice on how best to counter the charges. Incidentally, he mentioned his illness, then requested that Cromwell communicate with him through either Peter Vannes (Latin secretary) or Dr. Augustine. ${ }^{80}$ Some three weeks later Chapuis disclosed in a secret letter to Charles V that Lord Sandys had secluded himself at his country estate, The Vine, near Basingstoke, Hampshire, "pretending to be ill ....."Sandys' message to Chapuis had been brought by his physician, Dr. Augustine, whom Chapuis claimed to know. He added, "I like to make acquaintance with men of that profession [medicine], because they can come and go to all places without suspicion." 81

\section{PHYSICIAN TO THE KING}

The summer of 1535 marked the beginning of a new and successful phase in the career of Dr. Augustine, and for opening the way he was indebted to Lord Sandys. As lord chamberlain of the royal household, his influence, though somewhat reduced in 1535 , could be useful to ambitious men seeking careers at court. In his letter of 13 July to Cromwell he emphasized the medical service rendered to his family by Augustine. He then reminded Cromwell of his (Cromwell's) past favours to the physician, concluding his dispatch with the recommendation, "He is worthy to serve the King". Apparently nothing had come of it when, six months later, the physician approached Cromwell bearing another letter from Sandys, this one a more positive endorsement:

I beg your favor for the bearer Mr. Augustine and his preferment to the King's service. He says you are his special good master. He has done a great cure on me, else I had not troubled you. $\mathrm{He}$ is cunning in the science of physic, and has seen much, and with your old good mastership towards him, I beg he may have a determinate end in these suits ... At The vine. ${ }^{82}$

${ }^{80}$ Ibid., VII, 1559. 20 December 1534.

81 Ibid., VIII, 48. 14 January 1535. A later communication, Lord Sandys to Cromwell, 13 July 1535, written at The Vine, establishes Augustine as Sandys' physician. He told of the "sweating sickness" with which he was afflicted, then asked Cromwell's forbearance at the delay of Augustine's arrival in London. He had been detained not only by Sandys' illness but also by the illness of his daughterin-law. "I trust you will not be displeased at his absence," he wrote, Ibid., VIII, 1034.

${ }^{12} L P, X, 32.6$ January 1536. 


\section{E. A. Hammond}

Notwithstanding such overtures to Cromwell, Augustine did not immediately obtain appointment to the king's medical staff. He did, however, continue to practise his profession among the well-to-do in London. In May 1536 Whalley, comptroller of the mint, was his patient. ${ }^{83} \mathrm{~A}$ few weeks later, as an epidemic of "sweating sickness" swept through London, Robert Knyvet (Knevet), a member of Norfolk's household, lying ill with the ailment, received the attention of both Dr. Augustine and Dr. Wotton, who diagnosed the illness and prescribed bleeding. ${ }^{84}$

By late 1537 Dr. Augustine was one of the four physicians on the king's medical staff, the others being Drs. Butts, Bentley, and Michael de la So [de la Soo, Delasco] "poticary [sic, physician]". ${ }^{85} \mathrm{He}$ was one of the recipients of "brouches of gold" from the jewel collection of the recently deceased Jane Seymour. ${ }^{86}$ By March of the following year, Augustine was among the members of the royal household receiving regular wages from the Treasury, paid at the rate of fifty pounds per year with additional gratuities on New Year's Day. ${ }^{87}$ These payments continued on a regular basis until March 1541, and were augmented in June 1539, upon his appointment as physician-in-ordinary to the king, a position which paid an annuity of twenty pounds. ${ }^{88}$ These payments were terminated on 22 March 1541, when he received, "in lieu of $£ 20$ and $£ 50$ heretofore granted him," valuable lands from confiscated monastic properties in Hampshire, Somerset, and Wiltshire. ${ }^{89}$ Other properties in Suffolk and Salop also came into his use at about the same time. In addition to such holdings, Augustine also owned property in Langborne Ward in the City. A lay subsidy roll of 24 October 1541 lists his assets "in landes and fees" at seventy pounds on which a rate of seven pounds was to be paid. ${ }^{90}$

There can be no doubt that the endowments granted to Augustine from which he collected incomes for some four years, combined with fees and gifts received from his medical practice, had elevated him into the ranks of the moderately wealthy. Although he was physician-in-ordinary to the king, his practice was not restricted to

${ }^{83}$ Ibid., X, 875.

34 Ibid., XI, 162. Editor Gairdner here identifies the latter physician as Nicholas Wotton, M.D. It is more probable that he was Edward Wotton, B.A. (Oxon.) and M.D. (Padua), Fellow of the Royal College of Physicians in 1528. See W. Munk, Roll of the Royal College of Physicians, London, Royal College of Physicians, 1861, vol. 1, pp. 20-21.

${ }^{85} L P, X V I, 380$ (p. 185). There was also a complement of surgeons and apothecaries of whom the best known was Thomas Vicary. These medical members of the household are identified in $\mathrm{Br}$. Mus., Arundel MS. 97, which is printed in extenso as Appendix II in Thomas Vicary, The anatomie of the bodie of man, Pt. I, ed. by F. J. Furnivall and P. Furnivall, EETS, Extra Ser., London, N. Trübner, 1888, p. 103f. The editors, apparently uncertain as to the identity of de la So, style him "Doctour Mighel, phesicion," and elsewhere as "Doctour Mighell de la So, physician to Lady Mary."

${ }^{86} L P$, XII (ii), 793. Gairdner assigns this document to the year 1537. It is Br. Mus., Royal MS. $7 \mathrm{C}, \mathrm{xvi}, 8 \mathrm{a}$.

87 Vicary, op. cit., note 85 above, pp. 103-9.

${ }^{88} L P, \mathrm{XV}, 1032$ (p. 539).

${ }^{80}$ Ibid., XVI, 1500 (72b). The greater portion of these lands had been the properties of Hyde Abbey located just outside the wall of medieval Winchester. Augustine's holdings, to which he had been given a lifetime lease (apparently as a royal gift), are described in detail in P.R.O., Patent Roll, 27 July, 37 Henry VIII, mem. 7.

${ }^{\circ 0}$ Returns of Aliens in the City and Suburbs of London, 1523-1571, ed. by R. E. G. Kirk and E. F. Kirk, Aberdeen, Huguenot Society, 1900, 10 Pt. I: 47. An entry for 4 April 1544, set a value of $\mathrm{f} 66 \mathrm{13s}$. $4 d$. on these properties, located in the parish of St. Dionis Backchurch. 


\section{Dr. Augustine, physician to Cardinal Wolsey and King Henry VIII}

the royal household. Records relating to his practice are not abundant but it is known that between 1540 and 1544 he was in the service of the Manners family (the earls of Rutland). ${ }^{91}$ On 27 January 1543, a London client wrote: "Mr. Doctor Augustyne has delivered to me his counsel by writing (herewith), and a box of ointment for my sister's disease." 92 In addition, there are hints of other enterprises calculated to augment the physician's income. Royal grants for March 1542, for example, include a licence to "Augustyn Augustin, one of the king's physicians, to export 600 tuns of beer."93

The decade 1536-1546 found Augustine at the summit of his career. As a trusted member of the royal medical staff he was privy to much of the political and ecclesiastical intrigue which made life at court both interesting and perilous. A clever and experienced espionage agent, he had managed to avoid direct involvement in schemes and manoeuvres which resulted in disaster for many of his friends and acquaintances. Even the downfall of his patron, Cromwell, in July 1540 , seems not to have seriously jeopardized his position in the royal household. In the meantime he had settled comfortably, if not altogether securely, into the good life of the prosperous London burgher. He maintained a house in Langborne Ward and worshipped in the parish church of St. Dionis Backchurch. He dwelt in close proximity to the Italian colony doing business in Lombard and Fenchurch Streets and could claim as his associates many members of the bourgeoisie whose fortunes were in the ascendency under the mercantilist policies of the Tudor monarchs. At some unknown date, possibly as early as 1538 , he was married to a woman whose Christian name was Agnes and who was probably of English birth. The registers of St. Dionis Backchurch include the dates of christening of three children born to this union: Elizabeth, 17 September 1540; Alexander, 2 December 1542; Julius, 5 December 1544. ${ }^{94}$

A second daughter, Livia Elena, probably born in 1545-1546, is not mentioned in the parish register. She figures prominently, however, in Dr. Augustine's last will and testament and lived in London for most of her life, dying in 1597 (see below pp. 243-245). The elder daughter, Elizabeth, makes no further appearance in the records nor is she mentioned in her father's will. It is assumed that she died at an early age.

Augustine's professional success was crowned by his election, about 1536, to the Royal College of Physicians. In 1542 he became one of the four assistant censors (subsidiarii), and in September 1543, he was elected to the office of Censor, an honour which was conferred upon him again in $1544 .{ }^{95}$ Among his colleagues were England's

${ }^{91}$ The accounts of Elizabeth, Countess of Rutland, 1540-1541, list a payment of 22s. $6 d$. "in reward to Doctor Augustyne." Historical Manuscripts Commission, Rutland MSS (Belvoir), 4 vols., London, 1888-1905, IV, 47. Another payment, this from the next Countess of Rutland, Eleanor, is recorded for 5 November 1543. "Gevyn to Doctor Augustyne at divers times (over and beside $£ 410$ s. in the price of a gown of damask), 75s. Ibid., IV, 339.

${ }_{92} L P$, XIX (i), 67. Otwell Johnson to his brother, John Johnson, a merchant of the staple in Calais.

${ }^{93}$ Ibid., XVII, 220 (9).

${ }^{24}$ Register Booke, St. De'nis Backchurch Parish, ed. by Jos. L. Chester, London, Harleian Society, 1878, pp. 71-73.

${ }^{95}$ A lacuna occurs in the annals of the College for the years 1531 to 1542 . The precise date of Augustine's election therefore cannot be confirmed. Wm. Munk assumed it to have been "about the year 1536". Munk, op. cit., note 84 above, vol. 1, pp. 26-27. For the dates of his election to assistant censor and Censor see Annals of the Royal College of Physicians, vol. 1, fols. 4b and 5a. 


\section{E. A. Hammond}

most notable physicians, among them Edward Wotton, John Clement, Sir William Butts, Walter Cromer, John Fryer, John Chambre and Robert Huicke. He arrived too late to have known the great Thomas Linacre (d. 1524), and it is unlikely that he could claim acquaintance with John Caius, who only returned to England as M.D. from Padua in 1547.

During his years as court physician Augustine contributed to the preparation of a unique book of medical recipes-unique in that the king himself was one of the collaborators. The other contributors were Doctors Chambre, Cromer and Butts. ${ }^{96}$ These recipes, providing specific instructions for concocting ointments, plasters and poultices, although they contain few ingredients not generally used at least two centuries earlier, may be regarded as representative of the best physic practice of the times. They also suggest the degree of desperation imposed upon the royal physicians by the incurable ailments (particularly, ulcerated legs), which plagued King Henry for the last ten years or so of his life and rendered him, in the words of Dr. MacNalty, "a difficult patient". ${ }^{97}$ Yet the skills of the medical staff, no matter how novel or creative, were unavailing.

Throughout these years of influence and favour at court (1537-1546), Augustine appears to have continued to serve the king in the shadowy and hazardous by-ways of espionage and intrigue. Such activities are seldom matters of record, but existing evidence is sufficient to suggest that Augustine was still a useful spy. As a respected resident of the City, consorting regularly with alien tradesmen, especially those of the Italian colony, few men were better situated to ferret out international plots and conspiracies or to collect the common gossip to be heard in taverns and inns. The ubiquitous Chapuis once again provides a clue. In a communication to the emperor, dated 31 October 1540, he wrote: "Last week the Italian physician attached to this court, and very familiar with the Lord Privy Seal [now William Fitzwilliam], came to dine four times. I think he came to spy and to promote closer amity [between King Henry and Emperor Charles]-Evidently he came from the Lord Privy Seal."98

No more is heard of Augustine's sinister activity until the last year of King Henry's reign when the monarch's approaching death touched off a deadly struggle between the Howards and the Seymours for political control of the realm. The Duke of Norfolk well understood that the accession of Prince Edward, whose mother was Jane Seymour, would signal the eclipse of his own family. His efforts at compromise were unavailing, however, and the Seymour faction moved quickly to incriminate

\footnotetext{
6 This volume of ninety-four folios is now Br. Mus., Sloane MS. 1047. The recipes bearing Augustine's signature are found on fols. 27r, 28d and 93d. Portions are printed as Appendix IX in Vicary, op. cit., note 85 above, pp. 220-230.

${ }^{27}$ MacNalty, op. cit., note 9 above. This case study presents the available evidence relating to the king's illnesses and attempts to interpret the known symptoms in the light of twentieth-century medical knowledge. The author noted that the king had first suffered an ulcerated leg in 1527-1528, but was cured by Thomas Vicary. A fall from a horse produced a recurrence of the ailment in 1536, the accounts of which show that both legs were affected. From that year until his death in 1547 he was never free from the affliction.

${ }^{98} L P, X V I, 214$. I have rendered the calendared version in the first person, although I have not examined the original document in the Viennese archives. Dr. Augustine was the only "Italian physician" at the English court at the time.
} 


\section{Dr. Augustine, physician to Cardinal Wolsey and King Henry VIII}

both Norfolk and his son, Henry, Earl of Surrey.99

Among the damaging depositions taken against the Howards, father and son, was one of John Torre, a native of France residing in London. Torre recalled that during the years when Charles de Marillac was French ambassador to the English court (1539-1543), he had frequently gone to the embassy to visit Marillac's secretary, a fellow townsman and life-long friend. He further deposed that a woman kept by Marillac and later the mistress of one of Marillac's servants had "babbled" much about those she had seen coming and going at the embassy. Especially did she remember those who had come furtively by night or early morning, and at a time when England and France were on the brink of war. Among them were the Duke of Norfolk and his half-brother, William Howard, and others of whom "he only remembers that one was a doctor of physic, called, as he thinks, Doctor Augustine." Torre concluded, "If you don't believe me, go and ask the woman."100

What was Dr. Augustine about, one may ask, during those last six months of King Henry's reign when portents of difficulty, if not disaster, loomed about him? He knew as well as anyone that death would soon overtake the king; he also knew that his long association with Norfolk would establish him as an enemy of the Seymours and the Dudleys. He was much too experienced in the vagaries of court politics to misinterpret the signs of the times and he had no intention of being swept into the maelstrom. So he quietly went about setting his English affairs in order and relying on the favours he might receive from Wriothesley, the Lord Chancellor, he laid his plans to leave his adopted country. ${ }^{101}$

In the summer of 1546, probably in early July, he was granted a passport, approved by Wriothesley himself, which would make his departure legal.102 On 7 July the Privy Council authorized the Exchequer to pay to Dr. Augustine fifty pounds as the king's reward."103 Finally, also in July, a letter to Venice, requesting that certain privileges be granted to Augustine upon his return to his native city, was authorized. ${ }^{104}$ It is to be inferred from a subsequent document in the Venetian archives that the letter was addressed to the English ambassador in Venice, Edmund Harvell, asking him to petition the Council of Ten in Venice to grant to Dr. Augustine and his servants

99 This dramatic episode is too well-known to be recounted here. Surrey was executed on 13 January 1547; Norfolk, attainted and scheduled to die, was spared only by the death of the king on 28 January. The basic facts may be examined in Gairdner's introduction to $L P, X X I$ (ii), xxxi-1.

${ }^{100}$ Ibid., XXI (ii), 555 (6). It may be assumed that such visits as Augustine had made were in the interest of the Howard faction and under the cirumstances could have been regarded as treasonous. Marillac left London in late March 1543 and, in spite of the strained relations, his replacement, R. d'Aspremont, was received. The Torre deposition, which would certainly have incriminated Augustine, was probably not obtained until late 1546, by which time the physician had departed for the Continent.

${ }^{101}$ In the late summer of 1545 Augustine was granted three licences to alienate. Accordingly, on 25 August his lands in Salop were transferred to Thomas Lawley. Ibid., XX (ii), 266 (36). On 6 September his extensive holdings in Hampshire, Somerset and Wiltshire were transferred to Sir Thomas Wriothesley, while on the following day Sir John Jeremy and Humphrey Waren received his property in Suffolk. Ibid., XX (ii), 496 (pp. 231, 232).

${ }^{102}$ Ibid., XXI (i), 1165 (75).

${ }^{103}$ Ibid., XXI (i), 1241. This was the last payment made to Augustine for medical services in the king's household. He was not included among the beneficiaries named in the will of the king. Ibid., (ii), 634.

${ }_{104}$ Ibid., XXI (i), 1382 (9). Accomplished at the instance of Sir Wm. Paget. 


\section{E. A. Hammond}

permission to carry weapons with which to defend themselves in Venice. What dangers awaited the doctor upon returning to Venice, however, is not made clear. ${ }^{105}$ Anyway, the Council of Ten granted the request on 15 December 1546. One may conjecture, of course, that Augustine feared enemies from an earlier time who would make his return unsafe. This is borne out by the fact that he appears to have avoided Venice in his last years. That he feared foul play from the henchmen of Edward Seymour is certainly a remote possibility.

Many questions as to the physician's fate and whereabouts for the next five years, 1546-1551, remain unanswered. His departure from England obviously occurred prior to the arrest of Norfolk and Surrey toward the end of 1546. Under what pretext he left the service of the king one cannot say, but it was apparently accomplished without recrimination or embarrassment. Nor do we know when his wife and three young children joined him on the continent, if indeed they had not accompanied him. From his last will and testament (see Appendix) it appears that his English business affairs, which included loans to the king, were left in the hands of Antonio Bonvisi, head of the London branch of the Italian bank of that name, who was godfather to the Augustine children. It is also made clear in the will that the assets which Augustine had been able to liquidate earlier had been shrewdly invested at various places in western Europe, particularly in Antwerp, where Ludovico Bonvisi, in charge of the Flemish branch of the bank, was a financial adviser. Considerable sums were also on deposit or invested in Lyons, Venice, and Florence. One might assume then that business matters consumed much of his time.

A final intriguing and cryptic note on Dr. Augustine belongs to 4 March 1549, when the Privy Council approved a warrant to Sir John Williams, treasurer of the Court of Augmentations, authorizing him to pay to Stephen Fox, Yeoman of the Guard, $£ 416 s .4 d$. "for his charges in the bringing back of Dr. Augustyn, departing into Flanders." 108 In the absence of supporting documents this becomes a baffling bit of information. The only interpretation which presents itself is that the physician had dared to return to England-and there are many reasons why he might have elected to take such a risk-had been found out and had escaped once more to the continent, eluding the guard sent to arrest him. He had never been one to shy away from adventure.

For the last five years of his life, Dr. Augustine, though wealthy, was homeless. One is led to wonder why he did not settle with his family in Venice, the city of his birth, where the Augustine family was prominent in government and business. ${ }^{107}$ It may be inferred from his will that he divided his time between Italy and the Netherlands attending to matters of business, the vast extent of which is suggested in the document itself. It is also indicated in the will that his wife and children were residing

\footnotetext{
${ }^{105}$ Cal. St. Pap., Venetian, 1534-54, p. 182. This document translates as follows: “. . . to gratify the magnifico Ambassador from the King of England who has made the demand of the Signory with great earnestness, a licence to be conceded to the Doctor of Physic, Dom. Augustin di Augustini, authorizing him and two servants to wear weapons in Venice, he giving a note of said servants' names to the office of the State attornies." Ayes 13, Noes 2, Neutral 2.

${ }^{106}$ Acts of the Privy Council, ed. J. R. Dasent, London, 1890, II, 405.

107 The Sanuto Diaries contain numerous entries relating to persons named Augustine here and there in Italy, particularly in Venice.
} 


\section{Dr. Augustine, physician to Cardinal Wolsey and King Henry VIII}

in Italy, but whether in Venice, Mantua, Padua, Florence or Lucca one cannot be certain. ${ }^{108}$

The will also reveals the consuming interest of the testator in his own financial affairs and the meticulous care with which he arranged for the disposal of his property. He appears to have been mindful of every investment, every interest rate and every debt which was owed him. Many of his bankers are identified, viz., Guinigi and Balbani in Antwerp, Cavalcanti and Gerardi in London, the Giunti in Venice, and the previously mentioned Bonvisi in Lyons and Lucca. Such was his concern for the ultimate settlement of his estate that he was at various times and under various circumstances moved to produce "last" wills with his own hands-one in London, one in Padua, one in Venice-all of which were finally invalidated by that one which he wrote in Louvain on 12 April 1551, and which was itself altered by lengthy codicil dictated to his attorney as he lay on his death bed in Lucca on 14 September. ${ }^{109}$

"The magnificent and renowned doctor and physician, Doctor Master Augustinus de Augustini, Venetian citizen, physician of the English King of happy memory," as he was styled, died just six days later, on 20 September $1551,{ }^{110}$ in the home of Paolo and Giovanni Arnolfini in Lucca. The house stood in the Via Mustolio, in the parish of San Salvatore. If members of his family were present to offer comfort in his final hours, the records fail to mention them.

Thus ended the career of this man of the Renaissance, quietly in bed in the presence of friends and in his native land. He might well have died at the hands of the executioner on Tower Hill, or from a dagger wielded by the henchman of some political intriguer in the dark streets of Regensberg or Bologna or Brussels. Many of his missions were dangerous and on more than one occasion a false step would have been disastrous. Yet he was a skilful agent, seldom undiscerning and almost never incautious. It is difficult to assess the regard in which he was held by his contemporaries. Chapuis, who knew him well, seems never to have trusted him but looked upon him as a clever and useful spy. Cromwell, at times, relied heavily upon his intelligence while Norfolk, to whom he was of frequent service, never let him presume much friendliness. To both Wolsey and Henry VIII he was a shrewd medical adviser and little more. It may be of significance that, when death came to each of them, the physician had, perhaps intuitively removed himself to safer environs. George Cavendish, devoted as he was to Wolsey, regarded Augustine as an out-and-out traitor. ${ }^{111}$

It appears to the present writer that the judgments have been excessively harsh and based disproportionately upon Augustine's role in the downfall of Wolsey.With or without the testimony of Augustine, the doom of Wolsey was sealed long before

\footnotetext{
108 Among the provisions of the will is the following: "One thing I wish to request of my executors as insistently as I can: that under no circumstances with their mother or alone, shall my sons be permitted to go to England until they are sixteen or eighteen, and Livia ever be allowed outside Italy". See Will, Appendix I.

${ }^{109}$ The final redaction of the will is printed below as Appendix II.

110 This date is verifiable in P.R.O., H.C.A. (Libels) $24 / 4 / 22$.

111 Of the modern scholars who have set forth judgments on the physician, A. F. Pollard, after meticulous examination of the evidence, stopped short of branding Augustine villain. James Gairdner clearly regarded him a villain.
} 


\section{E. A. Hammond}

the ignominy at Cawood Castle. If one looks beyond the death of the prelate, it cannot be denied that Augustine was a useful but meagrely rewarded agent at the court of Charles V. As for his bountiful gains from the confiscated properties of the church, he was probably as worthy a recipient as the majority of those who profited therefrom. A materialistic opportunist he was indeed, but given the character of the times, it was a fault of no great magnitude. His subsequent rise to eminence within the medical profession-witness his election to directorial positions in the Royal College of Physicians, a rare honour for a physician of alien birth-indicates that he had earned the designation, "eximius" (distinguished) so frequently assigned to him. He was apparently, by the standards of the mid-sixteenth century, a superior medical practitioner, and it is obvious that Henry VIII so considered him. And finally, his solicitude for his immediate family, as well as more distant relatives, as demonstrated in his last will and testament, mark him as a man of compassion and even generosity. He seems a fair representative of his class and his times.

\section{EPILOGUE}

In spite of the painstaking efforts of Dr. Augustine to arrange for an incontestable disposal of his estate, the administration thereof proved to be exceedingly complex, resulting in a series of litigations extending over several decades. This was due not so much to the imperfections of the will as to the wide dispersal of his holdings, the incompetence of his male heirs, and the unreliable trusteeships established to manage his numerous bequests. ${ }^{112}$ It is not within the scope of this study, however, to provide the details of these legal battles. What follows instead is a brief account of the fortunes, good and bad, of Dr. Augustine's survivors.

One may only conjecture that Agnes Augustine, the physician's widow, and her children remained in Italy throughout the reigns of Edward VI and Mary I, perhaps awaiting a more favourable political climate in England. With the accession of Elizabeth I on 17 November 1558, conditions would have doubtless improved for the family of her father's physician, and yet there is no proof that Madame Augustine returned immediately. By the summer of 1562, however, she was in England and already the wife of Francis Alford, a gentleman of London dwelling in Salisbury Court, near Fleet Street. ${ }^{113}$ On 15 September 1562, Agnes was granted a lifetime annuity of twenty pounds as a gift from the queen. ${ }^{114}$ The only other clue as to the date of the return of the Augustines to London is suggested by the probation of the will of Dr. Augustine which was only accomplished at the Prerogative Court of

112 One notable example, involving the banking house of Giraldi and Cavalcanti, is documented in P.R.O., H.C.A. 24/41. This Florentine firm, with a London branch, had been assigned to manage Augustine's estate in Florence pending the coming-of-age of his heirs. As late as 1567, however, they had failed to release the inheritance. On the plea of Francis Alford, Queen Elizabeth twice requested the Duke of Florence (Cosimo de Medici) to intervene in the matter. Calendar of the Clarendon State Papers, ed. by O. Ogle and W. H. Bliss, Oxford, 1872, vol. 1, pp. 487, 495. There is another letter, dated at Richmond $20 \mathrm{July}, 1567$, in which the queen thanked the duke for complying with her request. Br. Mus., Royal MS. 13B, fol. 193.

118 Alford, member of a prominent burgher family, was a brother of the better-known Roger Alford, sometime Teller at the Exchequer. Francis' messuage stood just west of St. Bride's church. Salisbury Court later came to be known as Sackville Place. In the sixteenth century it was considered to be in suburban London. Cal. Pat. Rolls, 1563-1566, p. 108.

114 Ibid., 1560-1563, p. 273. No justification for such an award is provided in the document. 


\section{Dr. Augustine, physician to Cardinal Wolsey and King Henry VIII}

Canterbury on 20 June 1561, almost ten years after the physician's death.

It is very probable that Agnes' marriage to Alford would have been approved by Dr. Augustine. His bequest of five hundred marks carried only the condition that "if she wishes to remain a widow, which I do not think or advise," she should enjoy only the usufruct of the money. But in case of remarriage "either in Italy or England", there would be no strings attached. Since her three children were otherwise bountifully provided for, she was able to bring a handsome dowry to her second marriage. ${ }^{115}$ In the codicil to the will, he substituted 1500 gold ducats for the 500 marks.

Misfortune stalked the Augustine sons. In addition to the legal complications and interminable delays in obtaining their inheritances, both ultimately fell victim to mental disorders. Julius was only twenty years old when an inquisition taken at the Guildhall on 8 January 1565, with Mayor Richard Champion presiding, found him insane. ${ }^{116}$ On 19 February 1566 he was committed to the custody of his stepfather, who, upon the order of the court, received also the custody of the lands of Julius. It was stipulated that Alford account annually to the Court of Wards for the management of the property. ${ }^{117}$ Young Julius was living as late as the summer of 1567, when the queen sought the aid of the Duke of Florence in recovering for the two sons their property in Florence. ${ }^{118}$ Julius was dead prior to $1574 .{ }^{119}$

In the meantime, Alexander, who came of age about 1562-1563, had married one Margaret Conway, daughter of Edward and Alice Conway of Evesham, Worcestershire. The marriage was of very short duration, however, because of, as expressed by an acquaintance some years later, "some dislike growing between him and his wife."120 He too was declared a lunatic at an inquisition of $18 \mathrm{June} 1574 .{ }^{121}$ Notwithstanding his munificent legacy, his life was apparently one of wretchedness. His mother, either indifferent to his needs or unable to alter the course of events, allowed him to be removed to Bicester by Thomas More, husband of his sister Livia, on the promise that he would be well cared for. For his trouble More obtained from Alexander a loan of $£ 200$ to be repaid at specified times according to an obligatory note signed by him. ${ }^{122}$ But even before More's departure for Ireland in the summer of 1574 Alexander was put out to board with a succession of humble families in Bicester until his death, perhaps in late $1574 .{ }^{123}$

116 I have discovered only one clue as to the age of Agnes. On 5 November 1583, in connexion with a pending litigation, she was required to provide a deposition. In this instrument her age was stated as sixty. Since her first child, Elizabeth, had been born in 1540, when Agnes was seventeen, it would appear that her marriage to Augustine occurred when she was about sixteen. It was therefore not surprising that Augustine, as he approached death in 1551, placed no impediment in the way of a second marriage for his widow. P.R.O., Req. 2/278/29.

116 Abstracts of Inquisitions Post Mortem, City of London, Index Library, XXVI, London, 1901, II, 52-53.

117 P.R.O., C 66/1024/10, 11.

118 Cal. Clar. St. Pap., I, 487.

110 Absts. of Inq. Post Mort., II, 185-186.

180 It was so stated by John Baylie of Bicester in a deposition of 24 January 1583. P.R.O., Req. $2 / 278 / 29$.

${ }_{181}$ Abst. of Inq. Post Mort., II, 185-186. Margaret, the estranged wife, later married John Sheldon of Exeter. P.R.O., Req. 2/278/29.

122 Ibid. The loan was not repaid.

123 Ibid. John Baylie recalled having seen More from time to time hand over to Alexander pittances, "sometimes $12 d$. and sometimes 2 s. to buy necessary things." 


\section{E. A. Hammond}

More fortunate was the daughter, Livia Elena, who was handsomely provided for in her father's will. The youngest of the Augustine children, she was born about $1548,{ }^{124}$ although the parish register of St. Dionis Backchurch does not record her christening. She was married, probably in the late 1560 s, to Thomas More, son of Roger More of Bicester, bringing to the union a dowry of $£ 530$ of "lawful English money". ${ }^{125}$ Roger, a serjeant in the household of Henry VIII, had in 1542 come into possession of valuable properties once belonging to Bicester Priory, and subsequently returned there to enjoy the life of a well-endowed gentleman. ${ }^{126}$ Thomas, Livia's husband, was born about 1538, probably in London. ${ }^{127} \mathrm{He}$ came of age in 15581559 and shortly thereafter (12 April 1559) was given licence to enter upon his inheritance. ${ }^{128} \mathrm{He}$ had come into the service of the queen at a fairly early age, possibly on the recommendation of his stepfather, Michael Wentworth, a cofferer in the royal household and Master of the Household in the time of Queen Mary. ${ }^{129}$ In at least one document young Thomas More is styled "Gentleman Pensioner attending on the Queen's person". ${ }^{130} \mathrm{He}$ was presumably an acquaintance of the Alford family (Livia's mother and stepfather) as early as 1562 , when he was permitted to alienate some lands in Bicester and Wretchwick to Roger Alford, Francis Alford, et al. ${ }^{131}$ Early in 1574 he was sent to Ireland to assist in the suppression of a local insurrection, and there he was slain on 10 May of that year. All available evidence leads to the conclusion that Thomas was a wastrel and a spendthrift. His own inheritance was by no means insignificant, yet he was a profligate borrower. Just prior to his marriage to Livia he had received from the executors of the estate of Dr. Augustine the sum of $£ 530$ as her dowry. ${ }^{132} \mathrm{He}$ had then borrowed $£ 200$ from Alexander Augustine, as mentioned above. Nevertheless, at the time of his death his debts were estimated at between sixteen and seventeen hundred pounds. ${ }^{133}$ One might surmise that he had been much indulged by his family or that his proximity to the court of the queen had necessitated a style of living not supportable by his income. ${ }^{134}$

\footnotetext{
124 Abst. of Inq. Post Mort., II, 185-186.

125 P.R.O., Req. 2/201/6.

${ }^{126}$ For further genealogical information on the Mores of Bicester, see J. C. Blomfield (comp.) History of the present Deanery of Bicester, Oxford, 1882, and also his History of Bicester, its town and Priory, Bicester, 1884. See also John Dunkin, Oxfordshire: history and antiquities of the Hundreds of Bullington and Ploughley, 2 vols., London, 1823, and Victoria County Histories: Oxfordshire, VI, 22.

127 The two daughters of Roger More and his wife, Agnes, married into the gentry. Mary became the wife of Michael Blount of Maple-Durham, Oxfordshire, and to that marriage were born three sons, Richard, Thomas and Charles. Elizabeth More married (first) Gabriel Fowler of Tyselworth, Bedfordshire, and to this marriage five children were born. After the death of Fowler in 1582, she married Sir John Brocket of Brocket Hall, Hertfordshire. P.R.O., C 142/257/60.

${ }_{128}$ Cal. Pat. Rolls, 1558-1560, p. 98. This inheritance included lands in Bicester and Wretchwick, Oxfordshire, and part of a capital messuage in London, which his father, Roger (d. 10 September 1551) had held “of the Queen by knight's service." Ibid., 1553-1554, p. 3.

129 Cal. Pat. Rolls, 1557-1558, pp. 300, 442.

180 Ibid., 1569-1572, p. 354.

181 Ibid., 1560-1563, p. 420.

132 P.R.O., C 142/257/60.

138 This was the estimate of Laurence Eaton, who was serving as the executor of More's estate in 1577. P.R.O., Req. 2/201/6, fol. 3.

${ }^{134}$ It is recorded that on one occasion, in 1568, the queen included in her itinerary to Rycote, Oxfordshire, a visit with More and his wife at Bicester Priory, an event which had necessitated extensive (and presumably expensive) alterations to the hostelry of the Priory.
} 


\section{Dr. Augustine, physician to Cardinal Wolsey and King Henry VIII}

When his death came, unexpectedly, in 1574 his financial affairs were in a state of disorder.

Livia Elena did not long delay in taking a second husband, in this instance, "Thomas Swinnerton of London, Gentleman". The marriage occurred prior to 5 July 1576. On that date she and her husband filed a reply to charges made by Laurence Eaton, administrator of the More estate, who deposed that they had "privily and secretly," and in clear violation of the law removed "all the best household stuff, plate jewels, goods and chattels" of a value of $£ 200$ from More's house in Bicester. ${ }^{135}$ Furthermore, it was alleged that Livia Elena had received and converted to her own use certain monies owed to More. Eaton, faced with the obligation of paying More's debts, was pleading for court action to recover the missing movables.

Thereafter, Livia and Thomas Swinnerton virtually disappear from the records. Presumably they returned to London to the life of respectable burghers. It may also be assumed that she was permitted to retain a widow's portion of the More property in Bicester. Upon her death on 2 February 1597, this portion reverted to Sir Richard Blount, eldest son of Thomas More's sister Mary. Livia Elena Swinnerton died childless, thus bringing to an end the Augustine line.

\section{APPENDIX I}

\section{THE LAST WILL AND TESTAMENT OF AUGUSTINUS DE AUGUSTINIS*}

The preceding will was proved in the presence of the officer of the commissioner of the Prerogative Court of Canterbury in London on the twentieth day of June in the year of the Lord fifteen hundred and sixty-one, by the testimony of Margarita, widow, and Schiatta Cavalcante, executors named in this will who have been commissioned for the administration of all the goods and sworn in by the authority vested in Dino Compagni, executor in these matters at an earlier time, when he came and was admitted.

In the name of the Lord, Amen. In the year of Our Lord 1551 in the tenth indiction, on the 14th day of September, Lucchese style, in the presence of myself, notary public, and of his witnesses, specially summoned and authorized for the purpose, the magnificent and renowned doctor and physician, Doctor Master Augustinus de Augustini, Venetian citizen, physician of the English king of happy memory, his death being imminent, in the city of Lucca, spoke in person and explained that in the present year of 1551 when he was in Louvain, desiring to make a testament, wrote in his own hand a solemn last will signed and sealed by him, which he showed and presented to me, his notary, the sealed tenor and content of which is as follows: Viz,

Since I, Augustino Augustini, having made many wills in Venice, Padua and London, according to divers occurrences and changes, I now make the present will as my last one, invalidating all the previous ones. When the Most High shall be pleased to call me, I wish my body to be buried where I happen to be, without unnecessary pomp, with an ordinary funeral, even less than ordinary, and

135 P.R.O., Req. 2/201/6.

*This last will and testament of Dr. Augustine, now existing in the Public Record Office, London, was probated in the Prerogative Court of Canterbury on 20 June 1561, almost ten years after the death of the testator. It bears the number 24 in the Loftes register. The difficulties of translating the original will, written by the physician himself in his native Venetian dialect, were considerable, especially for the portions relating to financial and business matters. For generous assistance in this demanding task I wish to thank Mrs. Paola B. Langford, Gainesville, Florida; Dr. Florence Edler De Roover, Florence, Italy; and Dr. Charles H. Talbot, London, England.

Appendix II contains the codicil to the original will, drafted in Latin, by Antonio of St. Peter Santini of Lucca. The changes contained therein were dictated by Augustine as he lay on his deathbed in the house of Paolo and Giovanni Arnolfini in Lucca in the presence of the required witnesses. It bears the date 14 September 1551. 


\section{E. A. Hammond}

as soon as possible let alms be given for my soul as decided by my executors or by those living with me at the time of my last departure. I name as executors of my will the magnificent Messer Giovanni Francesco Copino, my uncle, and the magnificent Messer Geronimo Tuchato, secretary. I ask them both kindly and inviolably to make certain that this last will of mine be carried out, and I remit to both of them everything they owe me up to this time, so that in the future they may never be annoyed by my heirs. I appoint also as supervisor of my will the very magnificent Messer Antonio Bonvisi, my children's distinguished godfather, begging his lordship to accept such a responsibility in view of the particular trust I have in his uprightness; I also wish him to accept, in my memory, my largest goldplated salt cellar. I also desire that any two of them, coming to an agreement, may dispose of everything at their discretion. I leave to Messer Aloise Agostini, secretary, a total of two hundred ducats to be paid to him as he wishes after my death. And if by chance the above-mentioned Messer Giovanni Francesco should die before my children come of age, I wish his son, the excellent Messer Raffaello Copino, to take his place; to him after my death I leave all the books in my possession at the time.

I leave to Messer Piero Agostini 210 ducats, my relative, 10 per year, to help him in his poverty; likewise to Madam Lucia Agostini, poor widow of Messer Paolo, 10 ducats per year; 5 ducats per year to Madam Cecelia Agostini, pinsochera; ${ }^{136} 5$ ducats per year to each of the two nun-daughters of the above-mentioned Messer Giovanni Francesco Copino; and to Tannetto 3 ducats per year; to each of these for his lifetime.

I leave to my beloved wife, Agnesa Agostini, all her jewels, rings, necklaces, and all the household goods in my possession at the present time, with the exception of the children's garments and chains; [I desire] that she be paid the equivalent of $\mathbf{5 0 0}$ marks previously promised to her in England, ${ }^{13}$ ? as she wishes, [or] in case of remarriage either in Italy or in England. But if she wishes to remain a widow, which I do not believe in or advise, she will receive the usufruct of the above-mentioned 500 marks for her own use and for the management of the children, who will stay with her until they become of age, and for their expenses and clothing as much as my executors consider adequate. And if before or after my death some of the capital should be invested in estates in the province of Mantua, and particularly in the estates of C. Capriano or Buzzacharini, as the above-mentioned Copino is trying to do in the amount of 3000 to 4000 ducats, I wish to entail all of these estates to pass from heir to heir of the male line. In case my sons, Alexandro and Giulio, should die without male descendants, it shall be divided in equal parts between the sons of Messers Paolo and Piero Agostini under the same conditions. And from the income my above-mentioned wife, only if she remains a widow, will receive a living for herself and her children, and no other usufruct from the above-mentioned 500 marks of other income, which will go to the benefit of the heirs. And one thing I wish to request of my executors as insistently as I can: that under no circumstances, with their mother or alone, my sons be permitted to go to England until they are sixteen or eighteen, and Livia ever be allowed outside of Italy, so that they will be able to take advantage of their being English which will be much more profitable than much studying, provided they know a little Latin and be apprenticed to some merchant to learn to write business letters and keep books and to conduct business. They can start, little by little, to use their capital in good business practice. If my executors should disregard this wish of mine I will not give them [the executors] anything nor cancel anything they owe me; on the contrary, they will have to pay all their debts [to me] to the last penny.

To my daughter Livia, if spontaneously by divine inspiration, God forbid, she should enter a convent, I leave $\mathbf{3 0 0}$ ducats; if she should marry, and I mean always in Italy, I leave her 1500 ducats and something more, such as $\mathbf{2 0 0}$ or $\mathbf{3 0 0}$ ducats as my executors will decide, for a good match.

I want a sealed strong box of mine, left in Padua in the hands of the guardian of the Church of St. Francis, to be recovered and my will made there should be burned and a promissory note of

136 The word, pinsochera, defies accurate translation into English. In medieval and renaissance Italy a pinsochera, or pinsochora, was a widow or unmarried woman who took simple vows, dressed in plain costume, and received a small pension. In some towns pinsochere lived in special houses and in special districts. In Florence, for example, there is a street leading into the Piazza Santa Croce known as Via delle Pinsochere. Their counterparts in certain Flemish cities were known as beguines. In many places the pinsochere were noted for their piety and for their devotion to religious rites and obligations; in others their morality came into disrepute.

132 The mark did not exist in England as a coin but only as a money of account. It was valued at 13s. 4d., or two-thirds of a pound. In western Europe, however, it was an actual unit of weight for gold, from which gold coins were minted. In use was the term mark troy (marc de Troyes), weighing 245 grams. See R. de Roover, L'evolution de la lettre de change, xive-xviiie siècles, Paris, 1953, pp. 76-77. 


\section{Dr. Augustine, physician to Cardinal Wolsey and King Henry VIII}

100 écus ${ }^{188}$ made by the aforementioned Messer Giovanni Francesco given back to him; also one for 20 ducats [made by] Secretary Agostini should be given back to him or burned because I release him. Other notes should be retained and the guardian should receive as alms one Paduan bushel of wheat, or the corresponding value in money.

To Messer Galiotto Magallotto in Antwerp, as a remembrance, should be given two pounds groat [Flemish] ${ }^{139}$ to make himself a small ring. To Betta, my wife's maid, for services rendered I leave ${ }^{140}$ ducats for her maintenance. I appoint as full heirs of my present and future movable and immovable property my sons Alexandro and Giulio, in equal parts; if one of them dies without children, everything shall go to the surviving one. If they both die without male descendants, the immovable property, if such shall have been acquired, shall go in trust, as I have said above, to the sons of Messer Paolo and Piero Agostini, both deceased, and the personal property to their [Alexandro's and Giulio's] daughters, if they have any. If they have no children, 1000 ducats should be given to Livia, and the rest in equal parts, to the above-mentioned Agostinis. The estate I leave now is such [i.e., is in such state] because my books and other belongings have been stolen by Scots on the sea, and tormented by disease I have neglected my affairs up to now except for the promissory notes and accounts of those who have my money in their hands and are honest and upright: Owed to me by Messer Antonio [Bonvisi] and the heirs of Lodovico Bonvisi of Lyons, (as shown) by their letters of 11th March of this year during the Easter Fair, on deposit with the Court [or lent to the Court], 1650 écus of the Sun [écus de soleil], not counting the interest to be paid at the end of the month at $8 \%$ on a deposit of 2289/18s./3d. [with the Bonvisi] of mercantile écus and 18 écus au soleil received from Fortini of Lyons for the premium of a real insurance policy [securta] of mine, ${ }^{141}$ and from these [credits] is to be deducted 200 écus de marc that I had them draw for me in Antwerp last month.

In the hands of Guinigi and Balbani of Antwerp [there will be] $63514 s .8 d$. pounds groat Flemish, given to Martin Lopez [to repay] at the forthcoming Fair of Pentecost at $5 \%$. However, to be deducted are 20 pounds groat Flemish sent from Antwerp in écus au soleil, as appears in his letter of 12 February 1551. I have a credit with Messer Tommaso and Gianmaria Giunta of Venice for thirty pieces of calises ${ }^{142}$ sold to them with (credit) terms until next September of 293 ducats and 20 deniers, according to his account sent to me. In addition [there is a credit with the Giunta] for 1467 ducats, 1 denier for 150 pieces of colored kersey ${ }^{143}$ [i.e., dyed] sold for cash to themselves to be paid to me next September. In addition, 3 ducats and $31 / 4$ groats they wanted to make me pay for the tax for the consul of the Florentines [in Venice] ${ }^{144}$ as appears from the two accounts and their letters.

188 In this instance he did not indicate the kind of écu he intended. Coined at the time was an écu de marc, originating in Geneva and employed at the fairs there and elsewhere. It is probable, however, that the écu de soleil was here intended, since it was more widely used.

${ }^{139}$ Two pounds groat (Flemish), lire di grossi of the text of the will, obviously refers to the pond grooten Vlaamsch, based on the groat, a small silver coin, of Flanders. It is not to be confused with the Venetian pound groat worth twice as much. See R. De Roover, The rise and decline of the Medici Bank, New York, 1966, p. 34.

${ }^{140}$ The number of ducats was here omitted from the text of the will.

${ }^{141}$ It appears that Augustine was one of the underwriters of a bona fide insurance contract taken by Fortini for maritime or overland transport.

${ }^{142}$ The word calises as it appears in the Italian portion of the will presents a problem. In translating I have eliminated the possibility that chalices or goblets (Ital.: calice) was intended. It is more probable that carisea (pl. carisee), the English kersey (a lightweight woollen cloth, woven in England and much in demand on the Continent), was the commodity in question. See S. Battaglia, Grande dizionario della lingua Italiana, Torino, 1961- , vol. 2. Here the calisse is identified as an inexpensive woollen cloth, which is to be distinguished from calisea (calisee or carisea), the Italian term for kersey.

${ }^{148}$ In this instance Augustine used the word carisee. He was probably referring to kerseys in both instances.

${ }^{144}$ The concolato dei Florentini of Augustine's text refers to an agent of the Florentines living or conducting business in another city; in this instance, Venice. He was elected by the Florentines doing business in Venice and was from their own group or nazione; his salary was paid by its members, i.e., his fellow Florentines. He was not an official agent or envoy of the home government. In this instance Augustine was claiming that he should not be required to pay the fee for his business transactions in Venice, and that the Giunta should credit him with the sum deducted as a fee for the consul's salary. He obviously still regarded himself as a Venetian citizen, in spite of his naturalization in England and his continued absence from Venice. 


\section{E. A. Hammond}

In Florence from day to day I should collect by the hands of Tommaso Cavalcanti and Giovanni Gerardi for a quantity of tin sold by them for a net total of $807 \cdot 14 \cdot 4 \cdot$ ducats as appears in the accounts and letters sent to me. Likewise Tommaso Calvalcanti and Giovanni Gerardi of London [owe me] the interest on 200 pounds sterling at seven per cent per annum, according to the agreement with Bartolomeo Fortini by which they are for me all indebted to the King of England, and keeping in hand as much as possible, there is more interest and in this is included the interest due already nine months or more; and 30 pounds sterling sent by Fagnani the secretary [or the secretary sent for Fagnini]. There is a sum that I owe, but I do not know whether they [i.e., Calvacanti and Gerardi in London] or their agents in Venice paid the 108 ducats drawn on them by the said Giunti to pay the transport charges on my above-mentioned 108 pieces of colored kersey, because from the account of one or the other, this must be deducted.

And I want this to be my last and final will and as evidence of the truth I have written it and signed with my own hand and sealed it with my seal in the year 1551 on the 12th of April at 10 o'clock in the morning, by me Agostino Agostini, undersigned.

\section{APPENDIX II}

\section{DR. AUGUSTINE'S WILL AS REVISED BY HIS ATTORNEY}

Introductory statement made by Dr. Augustine's attorney: Furthermore he set forth in person how he was expanding his said last will and how much contained therein he would confirm and in what respects the aforesaid public instrument and last will was yet to be completed by me [his] notary by amplification, addition and alteration.

Thus Master Augustine, in a state of sobriety and sound mind, but as it pleaseth God's grace, languishing in body and confined to his bed, speaking properly and clearly, unwilling to depart intestate, has in person, by his last will and public testament, indicated orally the disposition of all his effects and goods, and has taken care to make his final testament in the following manner:

First of all, he humbly commended his soul to Almighty God. He wished to have his body buried as is directed in his written testament above in his own hand. Also he left for the work of the Holy Cross of Lucca one gold Italian scudo. Furthermore the said testator retrieves from the legacy of 200 golden ducats made to Messer Aloise Augustini, secretary, 100 golden Italian scudi because, when the said testator directed the 200 ducats to be given to the said Messer Aloise, as written above, it was done, as he says, solely in consideration of the little daughter [now deceased] of said Messer [Aloise] Augustine. Now he wanted from the said legacy to the said Messer Augustine 100 golden scudi to be set up for divine services for the departed son, ${ }^{145}$ and the other 100 scudi from the said 200 scudi to be given to the said Messer Augustine, he now bequeathed to Mistress Augustine, sister of the said Messer Augustine, for her marriage. In case she should not wish to marry, he leaves the 100 scudi to Cassandro, son of Messer Paolo of whom mention is made above.

The said testator, in order to indicate more clearly the bequest of 500 marks made to Mistress Agnes, his wife, as contained in the will written by the testator himself, bequeaths, instead of the 500 marks to his said wife, 1500 ducats in hard [latos=enduring] gold.

All categories of bequests made and assigned in the said testament written in the hand of the said testator [which] he made and ordained, and the will itself as written out and registered by me his notary as above, he bequeathed to persons specifically named by right of bequest and by the authority of this present last and public testament just as if these details were set down and repeated. And the testator desired that these details be observed as set forth, word for word just as contained above.

Apart from the said legacies, and after their deduction, he appointed as the universal heirs to his movable and immovable property, his rights and claims, Alexander and Julius, his male children, legitimately and naturally born to him and the said Mistress Agnes, his dear wife, in equal portions with the substitutions made in them and the dispositions described in the will, all of which are taken here as being arranged and described, just as the said testator wished them to be held.

The tutors and temporary guardians of the said sons, the executors and trustees whom he wanted to be appointed for his last will and testament he changed and appointed [instead] the eminent men, the Messers Francesco Copino, native of the glorious state of Venice, Antonio Bonvisi, citizen of Lucca, and John Geraldi, citizen of Florence, with the provision that two of the said three agreeing they shall be able to exercise and cause to be carried out everything [necessary] for expediting the

${ }^{145}$ The testator identified the son only as $i l$ figlolo. From the context one might conclude that he was a son of Aloise Augustine. 


\section{Dr. Augustine, physician to Cardinal Wolsey and King Henry VIII}

business just as though all three had met and consented. To all of whom, or to two of whom, in agreement about either the persons or the goods of his children, he has given and conferred total authority and power to execute every provision contained in the present testament in the same measure as he himself has, or would have were he alive. And as much as can by law be granted to tutors or guardians of minors, to the executors of wills, and all the aforesaid things, in the best way he possibly could. But since in the will or testament written by the testator himself as set forth above it is arranged that Master Jerome Zuchato, secretary, should be one of the executors and trustees of the will, and since he is to be relieved of all loans which he has received from the testator himself, the said testator has declared in a revision of his will that he is unwilling for the said Jerome to be an executor or guardian as stated in the original will written in his own hand, but he said that Master John Geraldi is to be put in his place. And this is because Master Jerome continues to remain in Venice and is occupied with his own business and because the sons of the testator will hereafter remain outside the city of Venice, and for this reason he has directed that the provision be changed, and has asked the said Master Jerome to pardon him because he cannot be tutor and executor any longer. And Master Jerome has signified to the testator himself that he was prepared to pay any debts which he owed to the testator. Furthermore, he declared that he did not intend to release said Jerome from debts which he owed the testator himself as he had been disposed to do in the testament written by himself and set forth above; that the loan which the testator himself had made to Master Jerome he believes to be of 100 ducats. Still, as was later shown, he was willing for said Master Jerome to be forgiven the said debt.

And this the said testator says it to be and he wishes it to be his last will and testament in confirmation of all the descriptions and annotations in the testament written by the hand of the testator himself and restated by me his notary as shown above [with] the exceptions, additions, and changes made by him as shown above in the superscribed sections respectively, and of such a kind as the additions and changes shown above.

All other terms set forth above in the hand of the said testator and revised by me as contained above he holds valid and orders and commands to be carried out by his executors, and if by the law of wills it [be held] invalid he wishes to validate it by a law of codicils, or by gift because of death or by any other better means, way, or law, by which the last wills of the dead can be rendered better and more binding.

Bringing to an end, cancelling, voiding, revoking and nullifying every other testament, and whatever other last will and codicil wherever made by him or made by the hand of his notaries, or by the hands of the testator himself under whatsoever words, limitations or abrogations, and under whatever concepts set forth that may be discovered. By this present will alone he wishes his effects to be disposed of and to precede the others. Concerning all the above the said testator asked me to make the requisite notarization into a public instrument for the proof of its verity.

Made at Lucca in the house of the heirs of Pietro Arnolfini, at this time Paolo and Giovanni Arnolfini, situated in the parish of San Salvatore, in the Via Mustolio, in a ground floor room of the said house where the said testator lay in bed, the said house being bounded by public streets on three sides, and on the other by the property of Christoforo Trenta, before and in the presence of witness Michele [son] of the late Alessandro Deodati, Benedetto [son] of the late Martino Bonvisi, merchants and citizens of Lucca, and Piero Bartolomeo from Codiponte, priest, sojourning in Lucca, witnesses summoned, called together and approved at the aforesaid year, month, hour and day. 